\title{
Discovery and Initial Documentation of USS NEVADA (BB-36): An Artifact of Two World Wars and the Advent of the Cold War
}

\author{
Michael L. Brennan ${ }^{1}$ (D) James P. Delgado ${ }^{2}$. Larrie D. Ferreiro ${ }^{3} \cdot$ Josh Broussard $^{4}$. \\ Michael Arbuthnot ${ }^{1}$
}

Accepted: 4 January 2022 / Published online: 31 January 2022

(c) The Author(s), under exclusive licence to Springer Science+Business Media, LLC, part of Springer Nature 2022

\begin{abstract}
The discovery of the sunken remains of the battleship USS Nevada (BB-36) by Ocean Infinity and SEARCH Inc. in 2020 provided the means for documentation, site mapping and characterization of a deep-water shipwreck with an iconic history that spanned a halfcentury of profound change in the world in response to two world wars, shifting geopolitics and technological development that concluded with the advent of the atomic age. The mission took place during a global pandemic reflected in how the project and subsequent survey were conducted. Ultimately, the wreck of Nevada is an artifact that speaks to the times and the societal changes the ship was part of and is a potent reminder of that era and how the ship, the Navy, and society at large adapted to issues and changes of the era.
\end{abstract}

\section{Introduction}

The veteran battleship USS Nevada (1912-1948) served in World War I, the interwar period, and in World War II. Badly damaged and sunk in the Japanese attack on Pearl Harbor on December 7, 1941, Nevada came to symbolize resilience and perseverance

\author{
Michael L. Brennan \\ mike.brennan@searchinc.com \\ James P. Delgado \\ james.delgado@searchinc.com \\ Larrie D. Ferreiro \\ lferreir@gmu.edu \\ Josh Broussard \\ Josh.broussard@oceaninfinity.com \\ Michael Arbuthnot \\ michael@searchinc.com \\ SEARCH, Inc., Jacksonville, FL, USA \\ SEARCH, Inc., Washington, D.C., USA \\ George Mason University, Fairfax, VA, USA \\ 4 Ocean Infinity, Houston, TX, USA
}


as it was quickly raised, repaired and returned to battle. Serving with distinction in the Atlantic and Pacific, Nevada ended the war as the oldest American battleship in service. Assigned to the target fleet for the first tests of atomic weapons at Bikini Atoll for Operation Crossroads, Nevada was the aiming point for the first test on July 1, 1946. Surviving that and the second test on July 25, Nevada was towed by navy tugs first to Kwajalein and then to Pearl Harbor. The decommissioned, irradiated and damaged Nevada was towed to sea and sunk in a naval weapons testing exercise on that ended on July 31, 1948 (Figs. 1 and 2).

A dedicated survey of the general area in which Nevada sank in April 2020 located the wreck in 4,715 $\mathrm{m}(15,472$ feet) approximately $120 \mathrm{~km}(\mathrm{~km})(65$ nautical miles) off Pearl Harbor. Following a systematic sonar survey deploying an autonomous underwater vehicle (AUV) from the vessel Pacific Constructor, an eight-hour dive with a remotely operated vehicle (ROV) conducted a detailed systematic survey of the wreck, which consists of the overturned, main hull of the battleship, and a number of targets in a debris field that covers a large area reaching some 1,968 ft $(600 \mathrm{~m})$ from the main hull (Fig. 3).

While an historic American battleship with an important symbolic significance for the American people, as an archaeological resource Nevada is one of a number of sites, including sunken vessels, that comprise a detailed archaeological record of the beginning of the atomic age and the Cold War, and specifically Operation Crossroads, the first tests of the new weapon at Bikini Atoll. That archaeological legacy is defined by the site of the tests at Bikini, the fleet of test vessels sunk there as a result of the two atomic

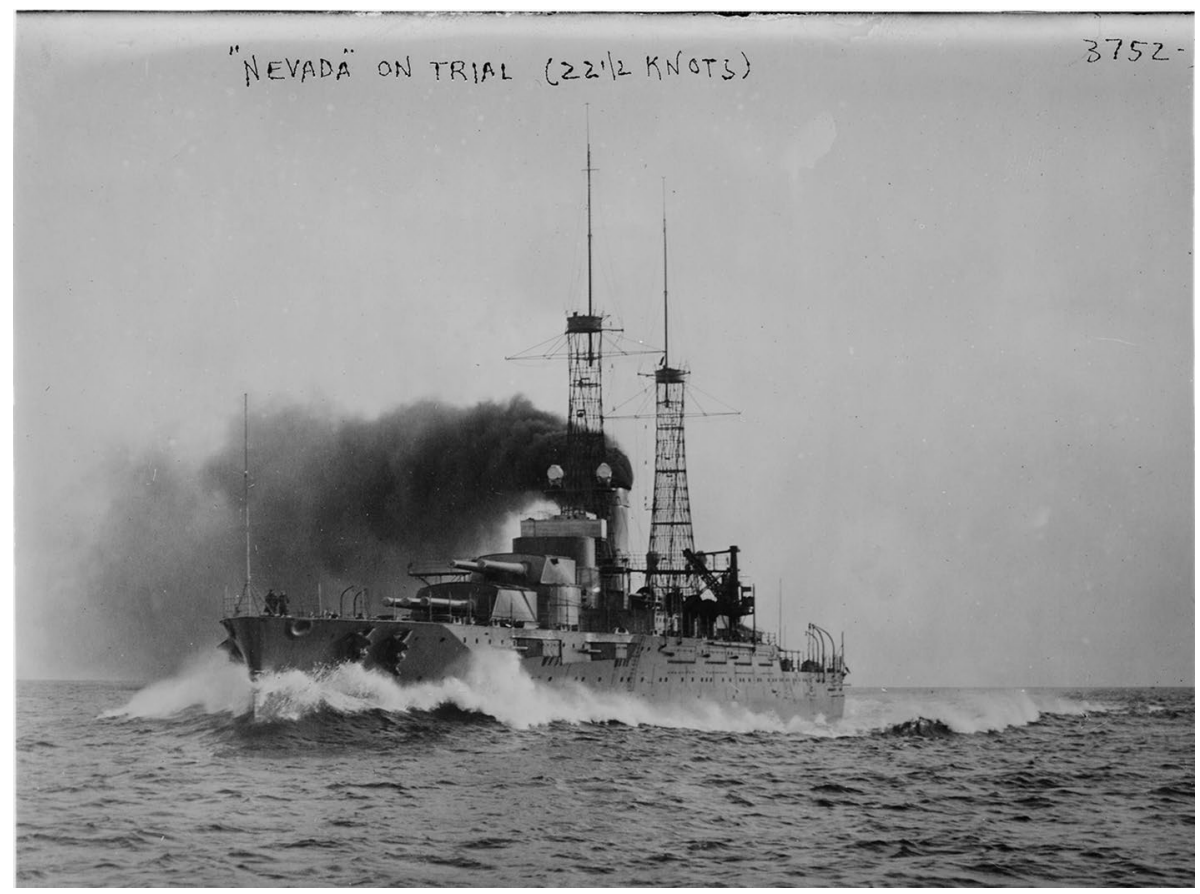

Fig. 1 USS Nevada during trials, c. 1916 (Naval History and Heritage Command/National Archives 21047u) 


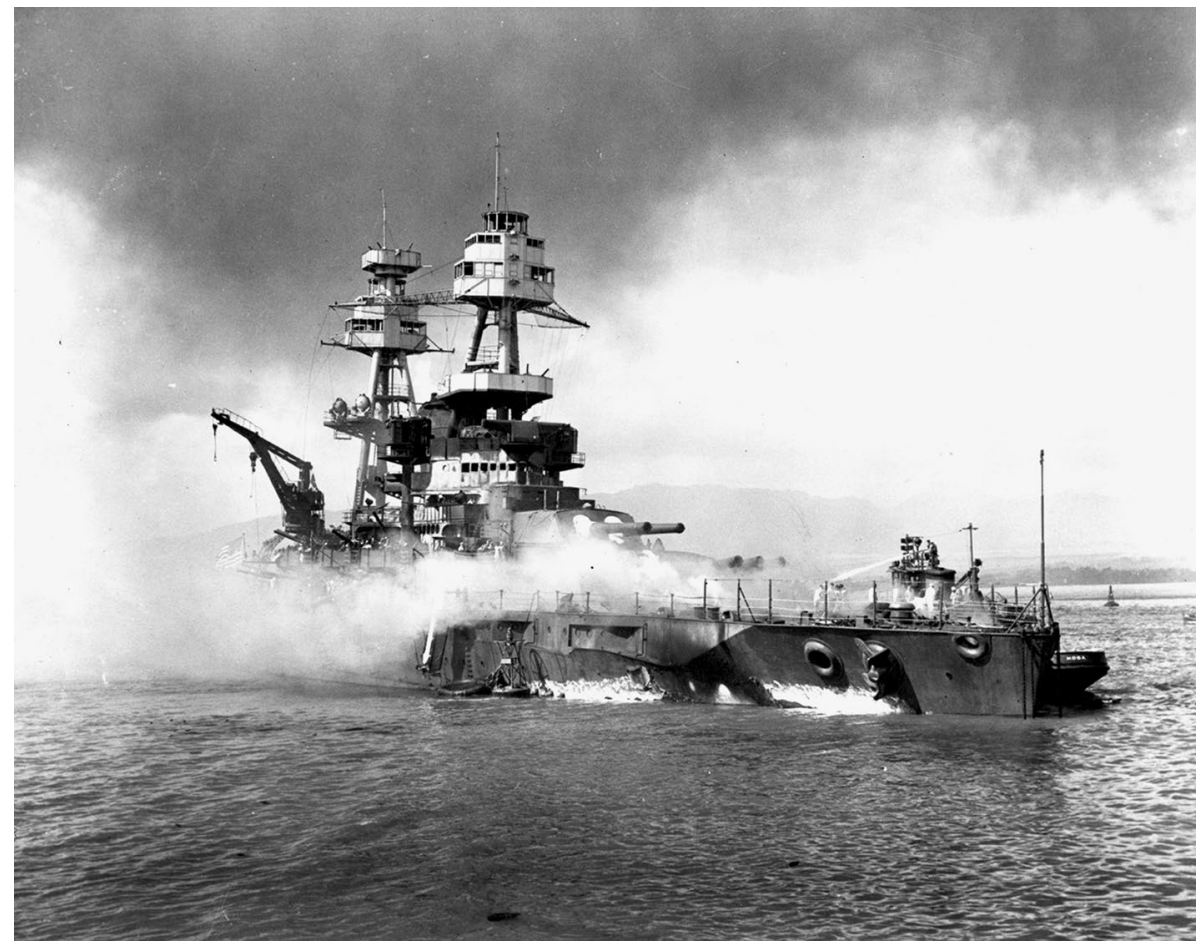

Fig. 2 USS Nevada damaged following the attack on Pearl Harbor on December 7, 1941 (Naval History and Heritage Command/National Archives 80-G-19940)

detonations, as well as vessels subsequently scuttled "in place" at Bikini. Bikini Atoll is a larger archaeological site and cultural landscape that reflects not only the 1946 tests, but subsequent nuclear weapons tests at Bikini through the hydrogen bombs tests of the 1950s.

The larger cultural landscape of Operation Crossroads, however, is broader with greater geographic distribution of individual wreck sites where associated facilities and artifacts associated with those ships and test equipment and artifacts associated from Crossroads comprise the historical extents of the sites. That includes shipwrecks directly lost at the time of the tests, and vessels which were subsequently sunk by the US Navy, most through scuttling or as targets in naval gun and aerial attack drills, as they were "outmoded" and "too hot to handle," or in at least one case, presumably in of fear of revealing atomic secrets through analysis of atomic residues.

Archaeological study of Bikini and material records of Operation Crossroads include initial work by the National Park Service in 1989-1990 (Delgado et al. 1991; Delgado 1996) and a detailed survey of the lagoon floor along with all associated wrecks of ships lost during Crossroads. This allowed a team from SEARCH and the University of Delaware in June 2019 to study them as a simulated nuclear battlefield that included the actual blast crater of the second test and its effect on lagoon sediment movement. Archaeological studies of Crossroads target ships moved to secondary locations post-test include the former German cruiser, Prinz Eugen at Kwajalein Atoll (Delgado et al. 1991; Delgado 1996), and the aircraft carrier USS Independence (CVL-22) off San Francisco (Delgado et al. 2017, 


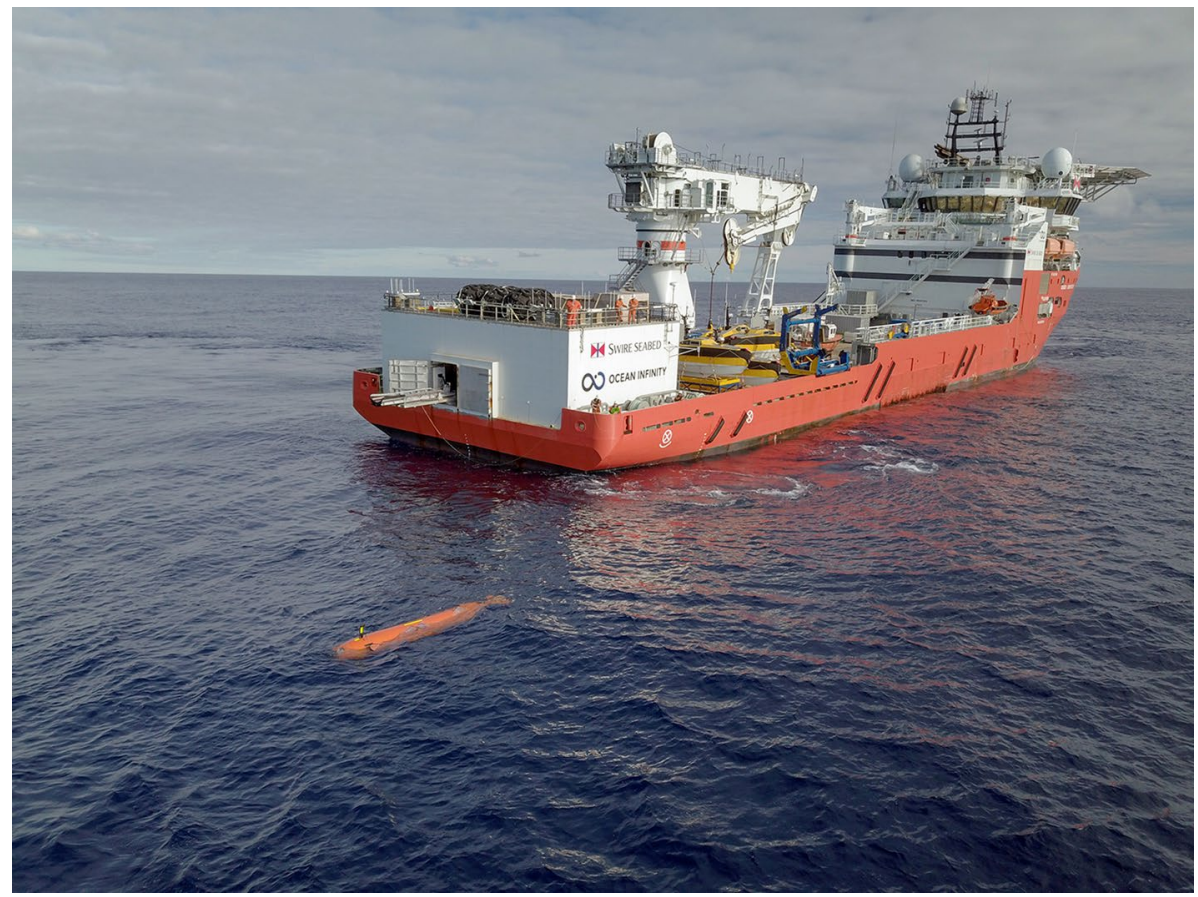

Fig. 3 Launch of HUGIN AUV from Pacific Constructor (Ocean Infinity)

2018a), and a separate study of naval aircraft also used in the Crossroads tests that remain in context at Bikini and on board the wreck of USS Independence (Delgado et al. 2018b). The wreck of USS Nevada is the next former target ship to be located on the seabed and archaeologically studied, and the first Crossroads target ship to be examined after being sunk as the result of a prolonged naval barrage.

\section{USS NEVADA, 1912-1945: the Ship as an Evolving Artifact of Naval Developments}

A dominant theme in the life of USS Nevada was the concept of an international arms race in which the battleship played a key role as the various great naval powers competitively built ships in larger numbers, but also with an emphasis on better ability to out-gun, out-pace, out-race and take more punishment and keep fighting; it has been described by one historian as the "cult of the battleship" with battleships representing not only national power and technology used for the purpose of waging war but also as the inheritors of the traditions of the wooden-hulled sailing ships of the line (O'Connell 1991: 3). Not only were these ships symbols of national pride and the projection of power, but for the Navy, as represented by its officers and crews, a way of life epitomized by ritual, social structure, and conceptions of "power, courage and fighting etiquette," unchanged by a transition to steel and steam, as the "single most important artifact" for naval professionals, symbolizing "everything that was acceptable and orderly about naval life" (O’Connell 1991: 3). 
Naval officers and proponents of sea power joined with politicians in the world's leading industrial nations to build larger fleets of increasingly larger, faster, better armored and harder-hitting battleships in an escalating naval arms race. This pre-World War I naval build-up was a major factor in stoking international tensions that led to World War I. Following the war, the major naval powers agreed to naval arms limitations talks that were held in Washington, D.C. in November 1921-February 1922. As a result of these talks, treaties that limited the fleets, size and armament of battleships were ratified after agreement between the parties (Fanning 1995:1-24).

The results of the treaties, which remained in effect until 1936, when Japan withdrew from the agreements, were a scrapping of a number of older ships, abandoning plans for ships under construction or rebuilding former cruisers into aircraft carriers, an increased focus on submarines, and a push to modernize and improve existing battleships. The design and refitting history of USS Nevada, like that of other warships not scrapped and remaining in service between the two world wars, reflects the results of these first arms limitations talks in world history (Jordan 2011). At the same time, countervailing forces of the postwar period also influenced Nevada, notably the development of submarines, naval aviation and, in time, the atomic bomb.

When laid down at the yard of the Fore River Shipbuilding Company in Quincy, Massachusetts, Nevada was the first of a "revolutionary" new class of battleships for the US Navy (Morison and Polmar 2003:63). Known as "Standard-type battleships," built and commissioned into service between 1911 and 1923, these near-sisters were the Nevada-class, with USS Nevada (BB-36) and USS Oklahoma (BB-37); the Pennsylvania class with USS Pennsylvania (BB-38) and USS Arizona (BB-39); the New Mexico class with USS New Mexico (BB-40), USS Mississippi (BB-41) and USS Idaho (BB-42). In addition, there was the Tennessee class with USS Tennessee (BB-43) and USS California (BB-44); and the Colorado class with USS Colorado (BB-45), USS Maryland (BB-46), USS Washington (BB-47) and USS West Virginia (BB-48) (Friedman 1978). Together, they (less the notcompleted Washington) were the powerful heart of the US Navy's "all gun" fleet in which the battleship was the central focus. In September 1915, as Nevada was readied to go to sea for trials, the New York Times noted that Nevada was "the world's most powerful battleship of her type" (New York Times, September 19, 1915). On October 26, the Times boasted that Nevada was larger than Britain's latest battleship, HMS Queen Elizabeth, and Nevada showed the "size and offensive and defensive strength of the newest of American sea fighters" (New York Times, October 26, 1915).

What set Nevada and its sister and near-sister battleships apart was their radical departure from the US Navy's first pre-century battleships built in the 1890s that had served with distinction in the Spanish-American War, as well as the first-generation "modern" battleships built in response to Britain's Dreadnought-class battleships in the first decade of the twentieth century as part of the naval arms race of the time. Nevada was larger and mounted more heavy guns, with ten barrels housed in four turrets; it was the first US Navy battleship to mount turrets with three guns as opposed to the earlier two-gun turrets (Morison and Polmar 2003:63). The turrets, mounted on the ship's centerline, were arranged with turrets 1 and 2 on the upper deck forward, with No. 2 elevated to fire over No. 1. Turrets 3 and 4 were on the aft main deck, with No. 3 elevated to fire over No. 4 . Numbers 1 and 4 "have three guns each and Nos. 2 and 3 two guns each" (Cox 1916:22) (Fig. 4).

Nevada was designed to operate with a steaming range of 8,000 nautical miles at ten knots and a top speed of nearly 21 knots (Cox 1916:20; Friedman 1985: 111, 13, 438). Unlike earlier battleships, Nevada did not require coal to steam, instead using fuel oil, which gave the ship greater range and also allowed for refueling at sea while underway. 


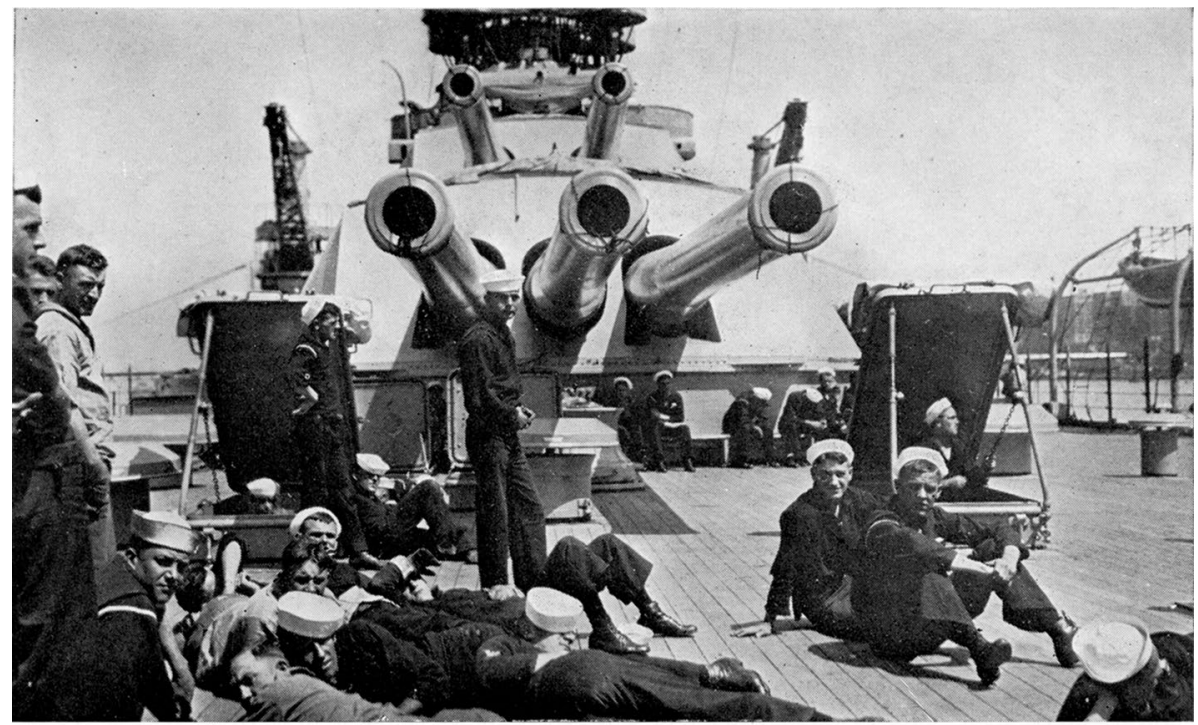

TURRETS AFT, U. S. S. NEVADA

Fig. 4 USS Nevada deck showing aft turrets (Naval History and Heritage Command/National Archives NH 104,614)

The first oil-fueled battleship in the US Navy, Nevada was powered by Yarrow water-tube boilers and Curtis geared turbines with a combined shaft horsepower of 26,500 that drove two propellers (Cox 1916:20, 22-41). This was a critical need as a longer cruising range allowed for a more global projection of American force, particularly in the Pacific in the face of increased Japanese militarization and expansion. As well, the design of Nevada incorporated a new approach to armor known as "all or nothing," which encased the vital areas of the ship in a thick "citadel" of heavy steel armor that protected the engines, boilers, ammunition magazines, the main battery of weapons, and command and control functions.

The outbreak of World War I in 1914 influenced US naval thinking even as the USA remained a neutral party. After launching and commissioning in early 1916, Nevada's first modification was the installation of 3-inch/50 caliber anti-aircraft guns as the airplane had made its military appearance, although naval planners, especially the advocates of the biggun fleet, failed to apprehend the deadly reality of aerial warfare at sea until the attack on Pearl Harbor 25 years later. Nevada was also fitted with flying-off platforms for aircraft that could be launched from sea and used to spot enemy ships (Friedman 1985:175-176-179). Following the USA' entry into the war in April 1917, American warships joined the British Grand Fleet, but Nevada did not cross until August 1918. At that time, excessive weight required that nine of Nevada's 5-inch/51-caliber guns (emplaced to defend the ship from destroyers) were removed.

Nevada's World War I service saw the ship serve as an escort for merchant convoys they joined from Bantry Bay, Ireland to Great Britain along with the battleships USS Oklahoma (BB-37) and USS Utah (BB-31). At the end of the war and brief service in which Nevada saw no combat, the ship returned to the USA after joining a larger force that escorted the liner carrying President Woodrow Wilson to the city of Brest for the Paris Peace Conference. World War I had introduced the submarine as an effective, deadly weapon against capital ships like Nevada, and the ship's first major refit in 1927 addressed that threat 
among other modifications. The ship's "yearbook" history succinctly addressed that following the Washington Naval Conference, "there were changes in naval thinking, in naval styles. Military uses of the airplane opened new vistas of combat possibilities. Too, the lessons learned in the first World War regarding submarine warfare had shown the need for additional protection against the torpedo," and so Nevada and its near-sisters were modernized with seven million dollars allocated to refit Nevada (Wyatt et al. 1946:13).

Hauled out at the Norfolk Navy Yard in August 1927, Nevada remained in the yard until January 1930 as workers modernized the battleship. The ship's propulsion machinery was removed, and the original triple expansion engines were replaced with steam turbines removed from the ex-battleship South Dakota (BB-31), which had been disarmed in 1924 and turned into a radio-controlled target ship for naval practice under the terms of the Washington Naval Treaty (Friedman 1985:186, 201). At the same time, the original boilers were replaced with six Bureau Express water tube boilers, and Nevada's fuel capacity was increased, which expanded the battleship's range, a critical change as the vast expanses of the Pacific were rapidly emerging as a strategic theater of concern, and war plans focused on an all-gun sea battle with a rapidly expanding Imperial Japanese Navy.

Torpedo blisters were installed along the sides of the ship that started above and extended below the waterline. Curved to fit the outsides of the hull, these water-filled steel casings served as barriers to absorb the shock of a torpedo hit, while water-tight bulkheads compartmentalized the damage. Additional armor was added to the deck for better protection from aerial bombing and shell hits, and the guns were refitted to gain greater elevation, which increased their range to 34,300 yards (31,400 m) (Campbell 1985: 121). The battleship's secondary battery, 5-inch guns located below the main deck in an "aircastle," were removed, and the compartments were sealed to become crew quarters. A new battery of 5-inch/25 caliber guns were placed around the superstructure on the main deck, torpedo tubes for firing those weapons were sealed off, and eight Browning machine guns were fitted as antiaircraft guns (Friedman 1985: 190, 201, 438). The original masts, interlaced steel structures known as lattice or "basket" masts, were taken out and replaced with steel tripods that mounted command and control structures, and would later also house radar. Two catapults were also installed, one at the stern, and the other atop the No. 4 turret, for aircraft that could be launched to search for enemy ships and help direct Nevada's gunners to targets (Fig. 5).

Nevada remained in its new configuration from 1930 until 1942, when it was extensively repaired and refitted after being badly damaged in the Japanese attack on Pearl Harbor. After emergency patching and refloating, Nevada was quickly rehabilitated to enable the battleship to take on crew and cross the Pacific for repairs and modernization at the Puget Sound Naval Shipyard (Wallin 1968:211-221; Madsen 2003: 20-21, 29, 75, 73-77). The focus of this refit, other than repairs, was shedding weight in order to add a substantial new battery of anti-aircraft weapons. The tripod mainmast was removed along with the thickly-armored conning tower. The older 5-inch guns were removed and replaced with eight dual-mounts carrying 5-inch/38-caliber guns, four on each side, thirty-six 40-mm Bofors anti-aircraft guns, mounted in nine quadruple mounts, and thirty-eight 20 -mm Oerlikon guns in individual mounts now ringed Nevada's midships, protecting the new, tall bridge that replaced the tripod mast (Gardiner and Chesnau 1980:91-92).

In its wartime service, Nevada served as an Atlantic convoy escort and provided offshore support for various landings and invasions, most notably at Normandy for the D-Day landings, where it heavily shelled German shore positions. Nevada then steamed back to the Pacific where the ship provided offshore firing support for the Iwo Jima and Okinawa landings in February-March, and March-April 1945. Off Okinawa, Nevada was damaged 


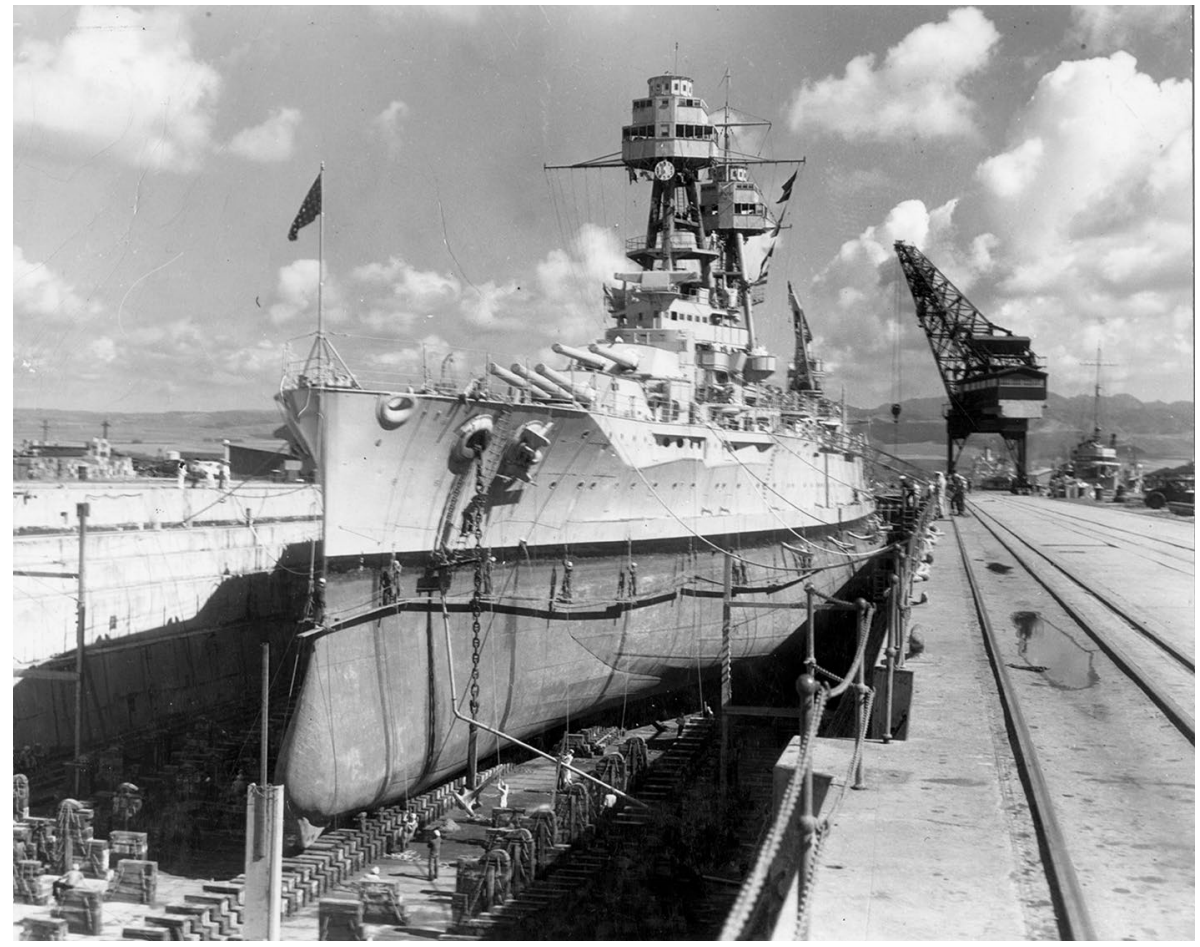

Fig. 5 USS Nevada in dry dock at Pearl Harbor, c. 1935 (Naval History and Heritage Command/National Archives NH 50,102)

during a kamikaze attack on March 27 when a single aircraft struck the ship near turret No. 3, taking the turret's guns out of commission along with three 20-mm antiaircraft guns, killing eleven men and wounding another 49 of the crew. Japanese shore batteries hit Nevada on April 5, killing two of the crew. At that time, the battleship's final configuration saw more anti-aircraft guns. The increase of an additional quad 40-mm Bofors and the $20-\mathrm{mm}$ guns ringing the superstructure at the bow and stern bring the total to twenty double-mounted and five single mounted guns. (Gardiner and Chesnau 1980:91-92). Modernized, and yet obsolete against aircraft-waged battle, with the end of the war in August 1945, USS Nevada faced an uncertain future.

\section{USS NEVADA at Operation Crossroads}

With the end of the war, Nevada was a warship that the US Navy no long required. The veteran Standard-type battleships and their surviving predecessors that had defined the biggun Navy of World War 1, winnowed at Pearl Harbor, now faced decommissioning, lay-up and in time scrapping between 1946 and 1959 (Table 1). Four of these battleships, USS Arkansas (BB-31), USS New York (BB-34), USS Nevada (BB-36) and USS Pennsylvania (BB-38), all veterans of decades of service, were selected as expendable targets in 1946 for Operation Crossroads, the atomic tests at Bikini Atoll in the Marshall Islands. Ultimately, 
Table 1 Prewar american battleship disposition, Post-1945

\begin{tabular}{lll}
\hline Name & Decommissioning date & Fate \\
\hline USS West Virginia BB-48 & 1947 & Scrapped, 1959 \\
USS Maryland BB-46 & 1947 & Scrapped, 1959 \\
USS Colorado BB-45 & 1947 & Scrapped, 1959 \\
USS California BB-44 & 1947 & Scrapped, 1959 \\
USS Tennessee BB-43 & 1947 & Scrapped, 1959 \\
USS Idaho BB-42 & 1946 & Scrapped, 1947 \\
USS Mississippi BB-41 & 1956 & Scrapped, 1956 \\
USS New Mexico BB-40 & 1946 & Scrapped, 1948 \\
USS Pennsylvania BB-38 & 1946 & Crossroads Target, Sunk 1948 \\
USS Oklahoma BB-37 & Sank at Pearl Harbor, 1941, & Sank underway for scrapping. 1946 \\
USS Nevada BB-36 & decommissioned 1944 & \\
USS Texas BB-35 & 1946 & Crossroads Target, Sunk 1948 \\
USS New York BB-34 & 1948 & Museum Ship, 1948 \\
USS Arkansas BB-33 & 1948 & Crossroads Target, Sunk 1948 \\
\hline
\end{tabular}

of all pre-1918 American battleships, most were scrapped, some in the 1920s and 1930s as a result of the naval arms limitation treaties, leaving no trace other than memories, photographs and relics. Physical remains persist in the wrecks of USS Utah (BB-31) and USS Arizona (BB-39) at Pearl Harbor, where they were sunk on December 7, 1941; USS Arkansas (BB-33) where it was sunk at Bikini during Operation Crossroads on July 25, 1946; and USS New York (BB-34), USS Nevada (BB-35) and USS Pennsylvania (BB-38), which were sunk in the deep waters of the Pacific. Of the four Crossroads American battleship wrecks, only USS Arkansas and USS Nevada have been archaeologically studied. The general positions for USS New York and USS Pennsylvania are known, and a NOAA sonar survey delineated a likely target for Pennsylvania off Kwajalein in 2017. Only USS Texas (BB-35) is readily accessible, set aside in 1948 for preservation as a museum ship outside of Houston in its namesake state (Power 1993).

After brief occupation duty in Buckner Bay, Okinawa, Nevada departed for San Pedro via Pearl Harbor on September 23, 1945. Those orders quickly changed to ferrying troops home as part of Operation Magic Carpet, but then again shifted to inactive status for experimentation, and finally orders for Nevada to serve as a target for Operation Crossroads. On January 1, 1946, Nevada was ordered to San Pedro for stripping to prepare it for Crossroads. While the main battery of guns were retained, almost all of the anti-aircraft guns were stripped except for four 5-inch/38 caliber guns, two twin 40-mm Bofors guns, and eight twin 20-mm guns (Bureau of Ordnance Final Report, 1946: 93, 94, 95). Nevada, assigned to Battleship Division 9 of Task Unit 1.2.1 (Battleships and Cruisers) of the target ship fleet, was also selected as the target aiming point for the first test, an airplane dropped bomb, as "the most rugged ship available" (Shurcliff 1947:6.10).

To ensure it stood out from the other ships in the target fleet, the Navy painted Nevada with a "high visibility paint" known as international orange, the bright color used on San Francisco's Golden Gate Bridge, and trimmed the decks with white to make the battleship stand out even more, so much so that at Bikini it was referred to as a "big, red lobster" and "the ship with scarlet fever" (Shurcliff 1947: 105; Weisgall 1994: 173). As well, to help 
simplify post-test damage reports, graduated draft marks were stenciled at the bow and stern, and large numbers delineated every tenth frame number from 10 to 140 on each side of Nevada (as was done on other target ships). A flashing white strobe light was also placed to help guide the pilots dropping the bomb on Nevada (Shurcliff 1947: 105) (Fig. 6).

In addition to the removal of guns and repainting, preparations for Nevada's role as a target included placing instruments on and inside the ship to measure the effects of the atomic blasts; these included pressure gauges, accelerometers and radiation measuring devices inside turrets and compartments as well as on deck (Bureau of Ordnance Group Final Technical Inspection Report 1946: 27, 29, 30). In addition to assessing the effects on the ship, a variety of military equipment and gear were placed on Nevada as a floating test platform, as was the case with the other targets. These included "armor plates and samples of known ballistic, chemical and metallurgical properties representing current manufacture of all types and gauges (sic)" on Nevada, USS Arkansas and the cruisers USS Pensacola and USS Salt Lake City "because their positions in the target array presented an exposure to the air burst at varying distances from and including the theoretical target. In addition, it was necessary to select vessels with large hulls such as battleships and cruisers with adequate space and deck support" (Bureau of Ordnance 1946: 210). The armor samples were secured with "heavy steel corner pieces welded to steel decks with heavy steel securing clips welded to corner pieces with clip and samples separated by wood and asbestos fillers. In the case of the four (4) heavy plates installed on the NEVADA, it was found necessary

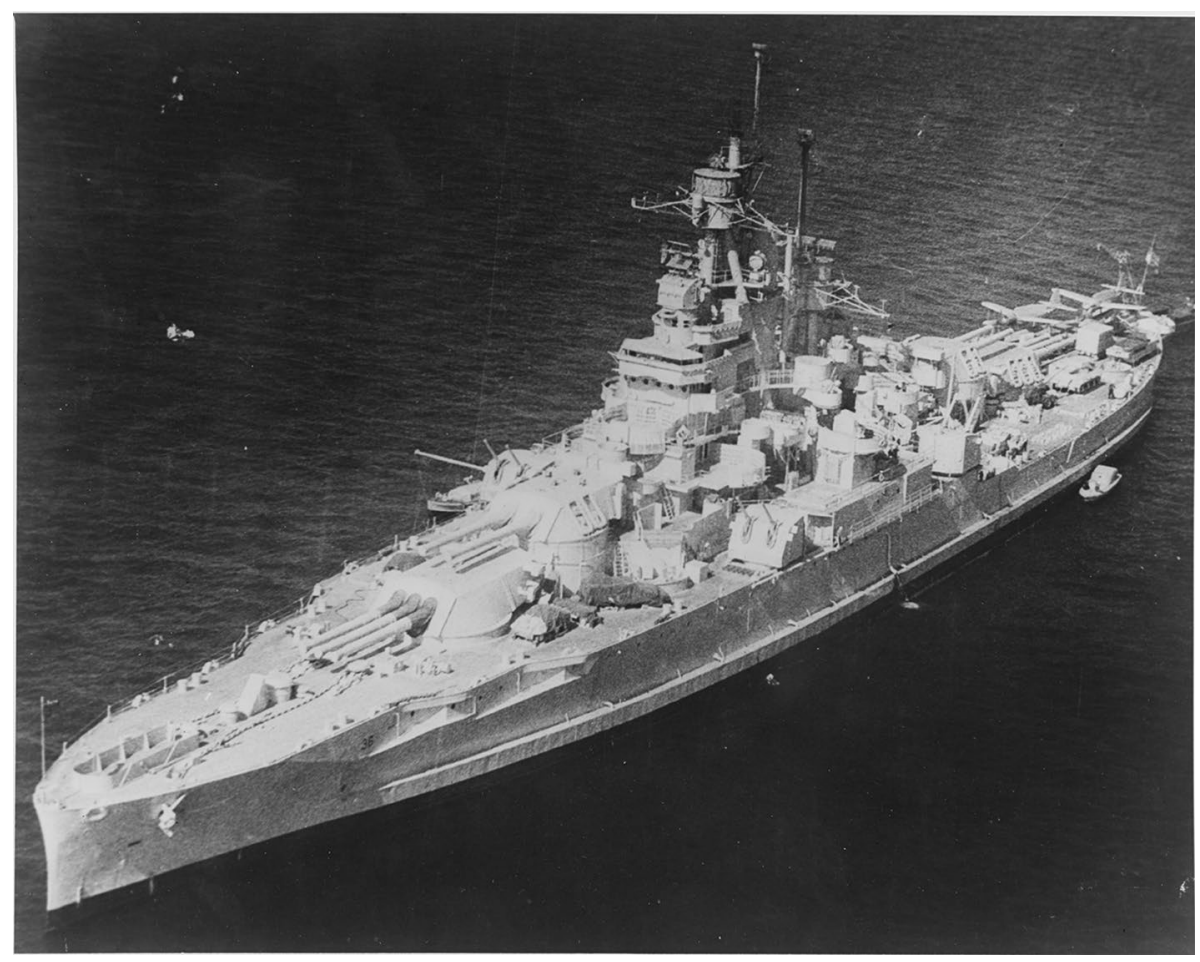

Fig. 6 USS Nevada painted orange as a target for Operation Crossroads, 1946 (Naval History and Heritage Command/National Archives 80-G-702620) 
to shore the area under the plates for two deck levels in order to provide adequate shock resistant supports for the heavy weight plates" (Bureau of Ordnance 1946: 210).

Seven armor plates were installed on Nevada and remained in place for both tests. After the Able test, "three metallurgical samples from each of the first four plates...were returned to the Naval Proving Grounds, Dahlgren, after the test for a comprehensive metallurgical examination in order to determine any effects caused by Test "A." Visual examination of the seven special armor plates aboard the NEVADA after Test "B" showed no apparent damage... "these plates will remain aboard the NEVADA until such time that the ship is available at a Naval Shipyard or other establishment having adequate handling and lifting facilities for their removal (Bureau of Ordnance 1946: 212). There is no record of recovery post-Crossroads, and it is likely that they remained on board the ship when it was sunk in 1948 (Table 2).

Military equipment loaded on Nevada included vehicles, weapons, electronics and a variety of other equipment. Major items included motorized 90-mm guns, Army heavy M26 Pershing tanks, and light M24 Chaffee tanks (Army Ground Group 1946: 23, 393) "All armored vehicles were secured to the deck by rods or turnbuckles from the towing links on the tanks to pad eyes on the deck..." and all tank hatches were closed and locked for the tests (Army Ground Group: 28, 37). A range of ammunition, both Army and Navy, was also exposed for the tests, some on pallets bolted to the decks, others stowed in ammunition-handling compartments or in loading trays for the guns. Nevada retained $66 \%$ of its wartime load of ammunition for its 14-inch, 5-inch, 40-mm and 20-mm guns; as the tests would also aid in assessing how ships would respond to atomic attack, they were loaded to varying degrees. Nevada's test load specifications were "Fuel oil 33.3\%, Diesel oil 50\%, Ammunition 66 2/3\%, Potable and reserve feed water 95\%, Salt water ballast 1850" (Bureau of Ships 1946b: 17). Plans for placement of test equipment prepared by the various task units at Bikini survive in the archival record. Among them is the "List of Ordnance Equipment," comprising the major test equipment placed on Nevada by Task Unit 1.4.3 (Ordnance) which locates each piece of equipment on a simple plan and also by deck, frame and side (port or starboard) (Table 3).

Crossroads preparations also included a medical section which placed test animals on board twenty-two target ships for Able and on four target ships for Baker to determine the effect of the bombs:

Goats, pigs and rats were selected as experimental animals for the atomic bomb tests for both scientific and practical reasons. These species vary in their physiologic response to ionizing radiations and provide therefore a wide range of pathologic changes. In addition they are hardy animals able to withstand tropical

Table 2 Armor plate samples installed on USS Nevada for operation crossroads (Bureau of Ordnance 1946:210)

\begin{tabular}{llll}
\hline Plate No & Type & Size & Weight $($ Lbs.) \\
\hline RR804 & Class A & $19^{\prime} 4^{\prime \prime} \times 10^{\prime} \times 12^{\prime \prime}$ & 96,600 \\
10,359 & Class B & $19^{\prime} \times 10^{\prime} \times 10.5^{\prime \prime}$ & 32,500 \\
35 E556A2 & Class A & $19^{\prime} \times 10^{\prime} \times 6^{\prime \prime}$ & 47,500 \\
TT415 & Class B & $18^{\prime} 8^{\prime \prime} \times 1^{\prime} 6^{\prime \prime}$ & 46,000 \\
12,263 & Class B & $20^{\prime} \times 10^{\prime} \times 3^{\prime \prime}$ & 25,000 \\
063,895 & STS & $214^{\prime \prime} \times 102^{\prime \prime} \times 2^{\prime \prime}$ & 2,000 \\
$65,835-B$ & STS & $20^{\prime} \times 6^{\prime} \times 0.5^{\prime \prime}$ & 2,400 \\
\hline
\end{tabular}


Table 3 Ordnance equipment installed on USS Nevada for operation crossroads (Bureau of Ordnance 1946:405)

\begin{tabular}{llll}
\hline Description & Deck & Frames & Side \\
\hline 90-mm Motor Carriage M36 & Main & $116-121$ & $\mathrm{P}$ \\
M26 Tank & Main & $109-115$ & $\mathrm{~S}$ \\
M24 Tank & Upper & 38 & $\mathrm{~S}$ \\
Half Track M16 & Upper & $42-46$ & $\mathrm{P}$ \\
105-mm Howitzer M2A2 & Main & 95 & $\mathrm{P}$ \\
155-mm Gun M1A1 & Main & 110 & $\mathrm{P}$ \\
40-mm Gun M2A2 & Main & 95 & $\mathrm{~S}$ \\
75-mm Gun (AC) M10 & Main & 121 & $\mathrm{P}$ \\
90-mm Gun (AA) M2 & Main & 120 & $\mathrm{~S}$ \\
Director M9A1 & Main & 111 & $\mathrm{~S}$ \\
Generating Unit M7A1 & Main & $1171 / 2$ & $\mathrm{~S}$ \\
Cable System M1 & Main & $1191 / 2$ & $\mathrm{P}$ \\
1/4 Ton Truck 4×4 & Upper & 40 & $\mathrm{~S}$ \\
Cargo Carrier M29C & Upper & 43 & $\mathrm{~S}$ \\
Truck Auto Repair M8A1 & Main & 130 & $\mathrm{P}$ \\
2 1/2 Ton Amphibian Truck & Main & 128 & $\mathrm{P}$ \\
45 “ Rocket Launcher & Main & 125 & $\mathrm{P}$ \\
Height Finder M1 & Main & 100 & $\mathrm{P}$ \\
Light Armored Car M8 & Upper & 37 & $\mathrm{P}$ \\
Small Misc. Equipment & Upper & 52 & $\mathrm{P}$ \\
81-mm Mortar & Main & $104-106$ & $\mathrm{P}$ \\
\hline
\end{tabular}

conditions and survive unattended on target ships which could not be reboarded for hours or perhaps days. Since these species have been studied in scientific experiments in many laboratories, a large body of data is available for comparison (Director of Ship Material 1946:186, 189).

At Bikini, Nevada received a contingent of goats and white rats for Able, causing one of the crew to reportedly remark "If those goats survive, I'm going to recommend our Chief Petty Officer for the next test" (Swaney 1986:122).

Departing Pearl Harbor, Nevada arrived at Bikini Atoll with a 403-man crew on the evening of May 28, 1946. The crew left the ship on June 30 to relocate to the attack transport USS George Clymer (APA-27) (Berkhouse et al. 1984: 364). On the morning of July 1, the Army Air Force B-29 "Dave's Dream" dropped a single Mk 111 plutonium "Fat Man" implosion bomb at 9:00 AM local time. Instead of exploding directly over Nevada, the bomb arced and detonated 2,130 feet $(649 \mathrm{~m})$ from the battleship, almost directly over the attack transport USS Gilliam (APA-57) at an elevation of 518 feet $(157.9 \mathrm{~m})$, which released a 23-kiloton blast that swept a wave of high pressure and intense heat, as well as radiation, across the fleet (Hansen 1988: 31, 38) (Fig. 7).

Post-Able inspection of Nevada by various technical groups noted a less-than catastrophic level of damage, contrary to what had been expected. Boarding did not take place until the morning of July 4 due to high radiation levels. On the superstructure, the highest point of the ship: 
Fig. 7 Test Able at Bikini Atoll during Operation Crossroads, July 1, 1946 (Naval History and Heritage Command/National Archives NH 85,804-KN)

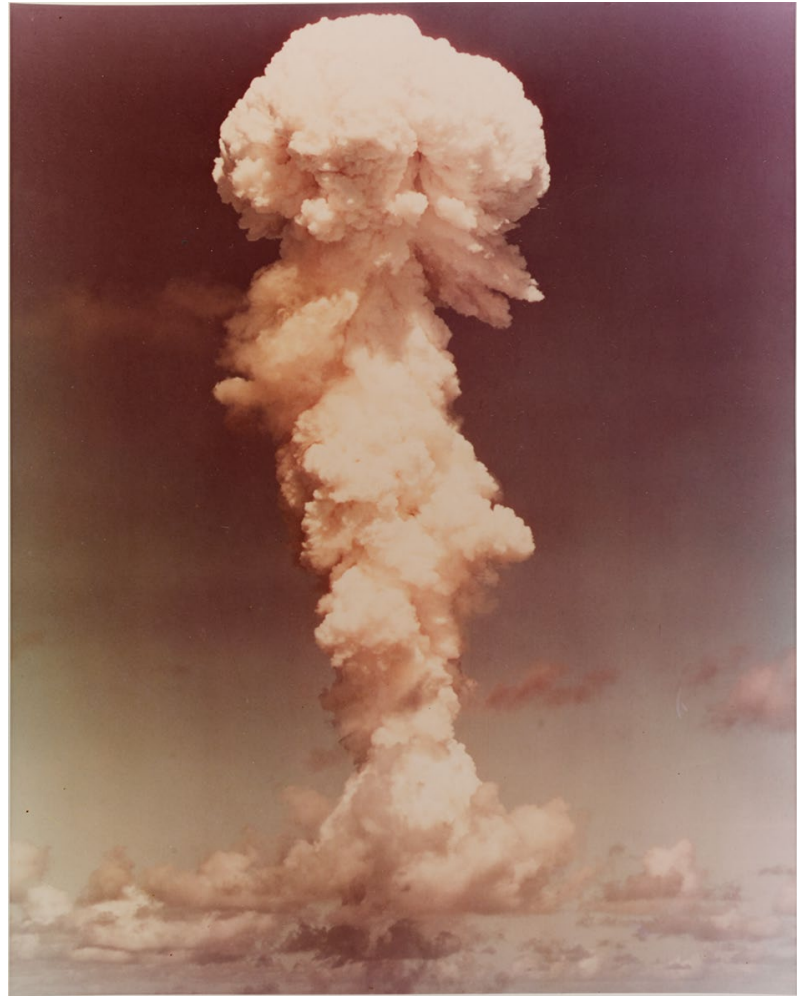

The sides and after face... are mildly dished, showing the almost undirectional effect of the blast. The critical plate weight appears to be about ten pounds, with an additional advantage in strength being indicated for curved surfaces rather than flat panel areas of identical weight. Light operational gear exposed to the blast such as antennae poles, radar screens, flag bags, and searchlights are carried away. Both topmasts are down. Handrails and light bulwarks are intact but damaged, and overhanging structure on the port side is deflected upwards a small amount Bureau of Ships 1946a: 5)

The deck "forward of the superstructure, is deflected between transverse bulkheads. Maximum deflections of four to six inches appear to starboard alongside of No. 1 turret. The deck beams and supporting structure conform to the deflection of the deck and the deck beams are distorted in way of their connections to bulkheads and shell stiffeners" (Bureau of Ships 1946a: 5).

The blast had pushed down with enough force to seriously dent the deck fore and aft:

The most severe depression is slightly aft of No. 4 turret...This depression pulled the deck away from the after face of No. 4 barbette. The maximum deflection in this area is about $161 / 2$ inches. Between frames 122 and 132 the maximum deflection is about 14 inches. The deflections of the main deck are accompanied by failure of supporting stanchions and distortion of connections of the deck beams to the shell stiffeners. The second deck is deflected aft of the armor from bulkhead 
122 to about frame 134, the maximum being about 12 inches. The damage diminishes as it goes deeper into the ship (Bureau of Ships 1946a: 6).

The blast also collapsed the plane-handling crane on the stern and damaged compartments where the deck had opened. It killed the ship's electrical systems, rendering Nevada "dead" and unable to fire even though the guns had no damage (Bureau of Ordnance 1946: 6, 10, 97, 111, and 112).

The radiation instruments, however, told a different story. The assessment of the ship's damage noted that "the amount of reduction in efficiency due to the high casualty rate among specially trained personnel because of inadequate protection from radiation and air shock, although unpredictable, appears to be of significance" (Bureau of Ships 1946a: 25). The general summary of observers' impressions and conclusions was more unequivocal:

Although the ship is in sound condition, structural protection against radiation and blast is inadequate. The destruction of masts supporting fire control, communications antennae, and venting of the blast into firerooms through the stack would have left the ship dead in the water and without adequate means of communication. Considering the time required to rig emergency repairs, this damage is believed to be critical (Bureau of Ships 1946a: 25).

Radiation levels declined to the point where Nevada's crew was allowed to return to the ship on July 8, where they remained on board until preparations for the second test, Baker, were completed.

On July 24, the day before Baker, Nevada's crew were again evacuated to USS George Clymer (APA-27) (Berkhouse et al. 1984: 364-365). On the morning of July 25, the Baker bomb, another Mark III weapon, was detonated by electronic signal inside a steel caisson suspended 90 feet $(27.4 \mathrm{~m})$ below the vessel LSM-60. The 21-kiloton blast lifted a 2000foot $(609 \mathrm{~m})$-wide column of water, sand and pulverized coral from the lagoon and threw it more than 5000 feet $(1,524 \mathrm{~m})$ into the air before gravity sent that mass back into the lagoon. Pressure waves of more than $6000 \mathrm{psi}(41,368.54 \mathrm{kPa})$ swept through the water as atomic tsunamis radiated from surface zero. Super-heated, highly radioactive steam swept across the fleet as well as displaced water as irradiated rain. Nevada, moored 1000 yards (914 m) from Baker, was hit but not sunk, while the battleship Arkansas, moored closer, was toppled and sunk in less than a second and hammered into the 180-foot (54.8 m) deep lagoon floor (Weisgall 1994:223, 225, Delgado 1996:xxx).

Post-Baker, Nevada was too irradiated to allow the crew to return to the ship other than for brief periods of duty to assess damage and recover instruments. Average topside radiation intensity recorded on the ship on August 19, 1946, was 1.1 R/Day (Phillips et al. 1985: 41). The technical report summarized the basic damage, which while not "sufficient to sink the ship...still caused considerable damage":

Outside of the light topside damage attributable to air blast or falling waters the only effect of Test B upon the ship appears below the waterline. This damage is believed to be directly attributable to a shock wave transmitted into the structure by the underwater pressure wave. This damage has resulted in the loosening of some foundation bolts, the breaking of pipe hangers, the scattering of equipment, and the opening of seams in the underwater shell (Bureau of Ships 1946b: 8, 89).

The forward turrets had partly lifted out of their barbettes, likely by the heavy wave action, or "underwater shock," and all "furniture, machinery and miscellaneous 
equipment not secured are overturned and thrown about, bunks and lockers are down, floor plates are dislodged" (Bureau of Ships 1946b: 10, 24).

However, the real issue was again radiation which, unlike Able, would not disperse in a matter of days. The ship was highly radioactive, inside and outside, and uninhabitable:

...the whole topside, decks, bulkheads, waterways, ladders and ventilators were covered by radioactive spray and water containing sand and coral which was highly radioactive. The ship also was covered by the atomic cloud or vapor. All of these, the radioactive water, spray and atomic cloud, left the ship in a highly radioactive condition. This in itself made the ship dangerous for personnel to live in or remain onboard and even though they may have escaped any direct exposure to the fission particles, they might soon have been seriously injured (Bureau of Ships 1946b:90).

A newspaper account of a post-test inspection of Nevada by a Geiger counter crew "moving gingerly, step by step," to find a "dying pig, in a 40-mm gun mount on the USS Nevada" that was "the most radioactive thing aboard that target ship. Its white corpuscles were nearly wholly consumed by the time the Geiger counter crew boarded the stricken ship" (Austin American 1946: 24).

The high levels of radiation at Bikini led to the cancellation of Operation Crossroads' scheduled third, deep-water test, and the swift removal of the support fleet and all surviving target ships capable of being steamed or towed away (Weisgall 1994: 235-245, 260). On August 11, in the face of ongoing danger from radiation, Admiral William H.P. Blandy, in command of the tests, asked the Chief of Naval Operations "for permission to switch the task force's base to Kwajalein... On 19 August the task force was ordered to shift base to Kwajalein" (Berkhouse et al. 1984: 130). Kwajalein was the initial base of operations for "radiological studies and other purposes" that included offloading ammunition and continuing various experiments in decontamination (Fee 1946: 65).

Nevada's crew (now 19 officers and 305 enlisted men due to assignments to other ships) unable to return to their ship, were transferred to the more lightly contaminated target ship USS Cortland (APA-75) on August 18, to follow Nevada to Kwajalein Atoll (Berkhouse et al. 1984: 365). Towed by USS Preserver, Nevada arrived at Kwajalein on August 22 (Berkhouse et al. 1984: 365). Twenty-one target ships from Operation Crossroads remained at anchor at Kwajalein until scuttling began in February and continued through May of 1948. However, eleven ships had been selected to go to naval shipyards for further study after a stop at Kwajalein. Nevada, along with USS New York, was slated to go to Pearl Harbor (Fee 1946: 65).

\section{Disposition of USS NEVADA, 1948}

Upon arrival at Kwajalein, Nevada joined a group of battered, irradiated hulks that were still loaded with ammunition and fuel. Nevada had 1,100 tons of ammunition in its magazines that required removal (Berkhouse et al. 1984:121). Some of Nevada's ammunition was offloaded three months after Baker on October 14 and then again from October 26 through November 5, 1946 (Philips et al. 1985: 39). While some ships were completely offloaded and their ammunition dumped, when the time came for Nevada to leave Kwajalein several months later, two-thirds of the normal allowance of ammunition still remained aboard due to the difficulties of removing 14-inch heavy shells with Kwajalein's inadequate facilities (Berkhouse et al. 1984: 125). There was also the problem of radioactivity. The 
average topside radiation readings on August 19, before leaving Bikini, twenty-five days after Baker, were $1.1 \mathrm{R} /$ day; of the various ships surveyed, Nevada was one of eight with readings higher than $1.0 \mathrm{R} / \mathrm{day}$, one of three at 1.1 , but not as high the maximum reading on another ship, which was 3.1 (Phillips et al. 1985: 41). Working from available data, scientists calculated reconstructed doses on Nevada post-Baker at $1.510 \mathrm{R} /$ day (Berkhouse et al. 1984:230). The levels did gradually decline; the average topside intensity calculated for Nevada, based on measured rates of decay, would have been 0.099 R/day on January 1 , 1947 (Berkhouse et al. 1984: 59).

Nevada departed Kwajalein under tow for Pearl Harbor, arriving on May 15, 1947 (Berkhouse et al. 1984: 49, 58). Moored in East Loch, Nevada sat at anchor for little over a year. Posted signs warned anyone not taking radiation readings "Danger Keep Off." There the ship remained until the 1948 decision to begin sinking the most damaged, and radioactive target ships, most of which were still at Kwajalein. On June 9, an article in the New York Times, quoted in the Proceedings of the United States Naval Institute, noted that Nevada, along with the battleship USS New York, also at Pearl Harbor, would be sunk off Oahu in July. "The Navy has been conducting tests with other Bikini victims in the past five weeks to sharpen Pacific Fleet's teeth in experiments involving the Navy's non-atomic weapons in event of an emergency" (United States Naval Institute 1948: 1036). After New York was sunk in early July, Nevada was to be

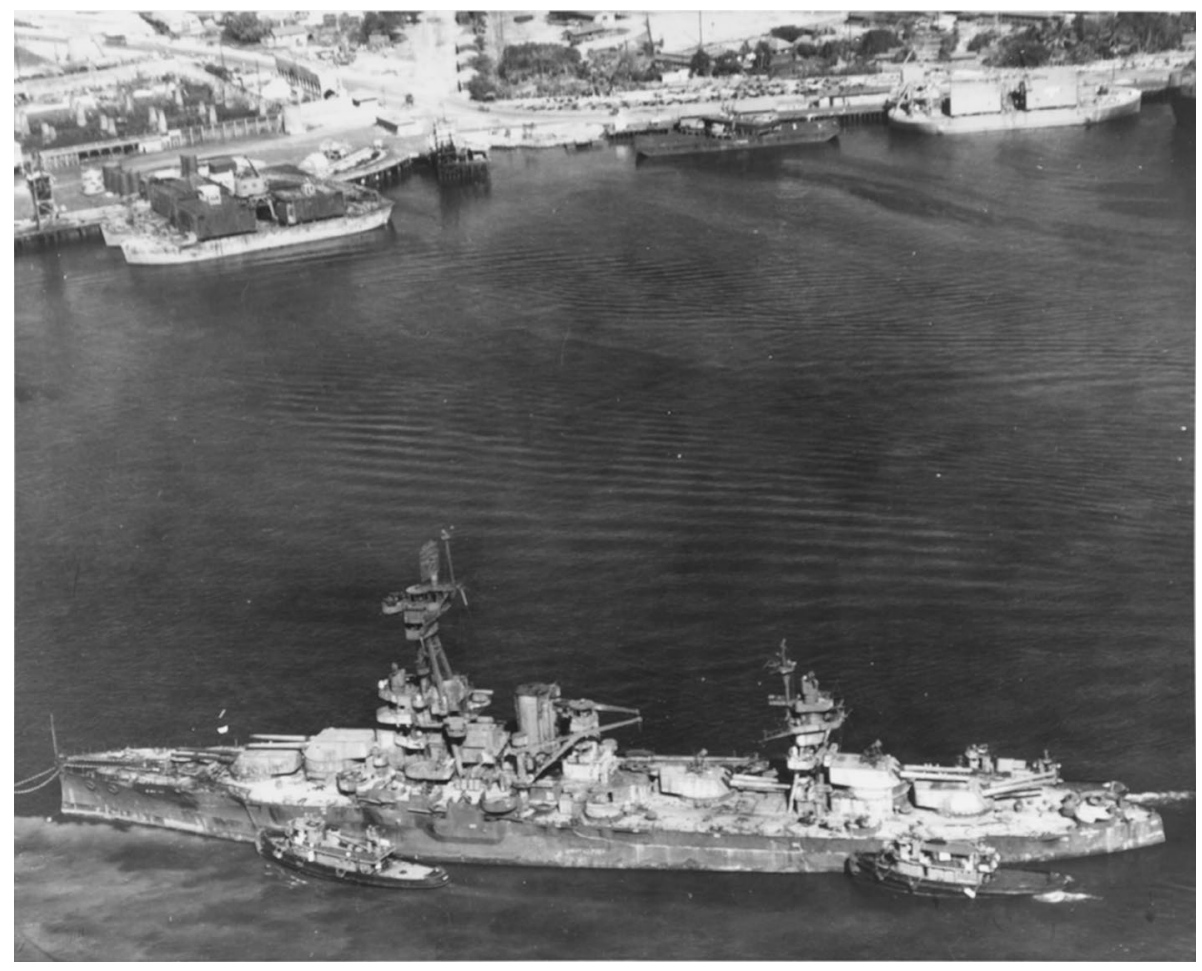

Fig. 8 Damaged after Test Baker during Operation Crossroads, USS New York arrives at Pearl Harbor under tow from Kwajalein, March 14, 1947 (Naval History and Heritage Command/National Archives 80-G-371904) 
sunk after it was "first used to test new types of explosives and then turned over to the battleship Iowa and the cruisers Springfield, Astoria and Pasadena for the coup de grace" (United States Naval Institute 1948: 1036) (Fig. 8).

On July 26, the Navy tug Jicarilla (ATF-104) towed Nevada out to sea where "a powerful new explosive device was tested aboard...only to detonate without causing significant damage," (Scarpaci 2014). An Associated Press story stated that "New and still secret explosives were put aboard and touched off. The Nevada's deck and side plates buckled, three holes were ripped in her sides, but she wouldn't go down" (Associated Press 1948: A-3). A United Press (UP) report filed on July 30 noted that after four days of attacking, a task force arrived to "end the 32 year career of the USS Nevada," and found it 62 miles from Oahu, "listing five degrees to port," with "great gaping holes in its starboard quarter from the effects of four days of secret navy explosives tests... the ship, still wearing the orange paint which marked it as the target vessel during the Bikini A-bomb tests... showed great rips in her deck, a large hole at the waterline on the port side and a slight upbend at its starboard bow from the blasts set off earlier in the week" (United Press 1948: 4).

Nevada was then fired on by the battleship USS Iowa (BB-61) and the cruisers USS Astoria (CA-34) and USS Pasadena (CL-65) on the afternoon of July 31. Opening fire at $1321 \mathrm{~h}$, Astoria shot at Nevada with 56 rounds of 6-inch/47-caliber shells, followed by 40 rounds of 5 -inch/38 caliber shells, expending all of the ammunition on board for

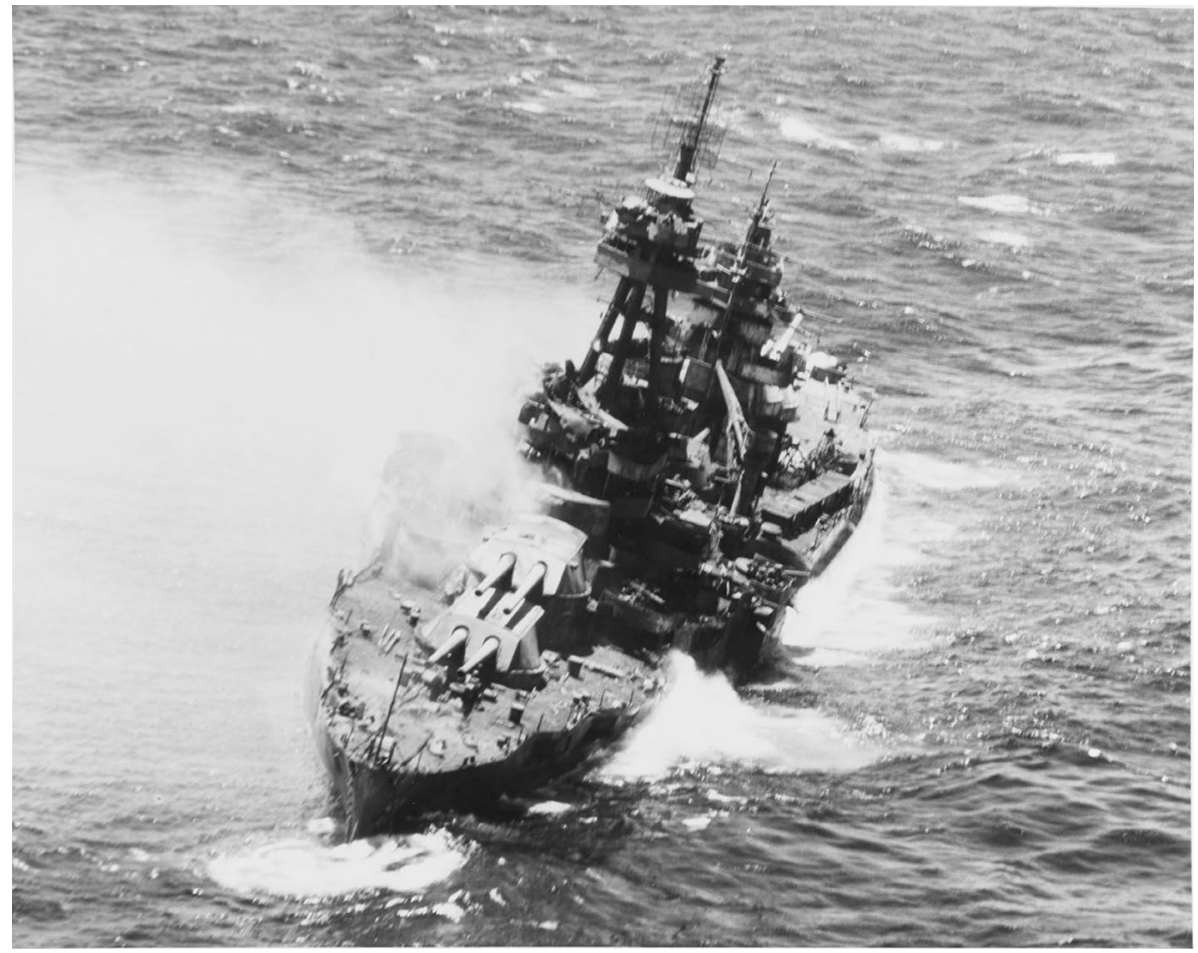

Fig. 9 USS Nevada as a target, July 31, 1948 (Naval History and Heritage Command/National Archives 80-G-498140) 
the exercise (USS Astoria 1948). "Destroyers pecked at her. Rocket-firing planes blazed away. Planes loosed radar-guided bat bombs, which missed. The Nevada still rode the waves" (Associated Press 1948: A-2) (Fig. 9).

Pasadena shot at the battleship with 57 rounds of 6-inch shells and another 57 rounds of 5-inch shells (USS Pasadena 1948). Iowa then opened up with 27 rounds of 16-inch/50 caliber shells, and then expended 50 rounds of 5-inch shells (USS Iowa 1948). In all, 27 16-inch shells, 113 six-inch shells and 147 five-inch shells, for a total of 287 rounds, were fired at USS Nevada in the space of twenty minutes. The battleship once touted as "too tough to die" was still afloat. In all, after four and half hours of shelling, and a "tremendous hammering by 14 warships and 60 warplanes," a final five aerial torpedo strikes "opened her side and she sank stern first within a minute after the last one hit" (Wagoner 1948: 16). Nevada capsized and sank at 1435 (Astoria 1948). As the Associated Press story noted, Nevada finally went down "after four-and-a-half days of trying" (Associated Press 1948: A-2). USS Iowa

...then moved slowly over the spot where the Nevada went down 66 miles southwest of Honolulu. The crew in dress whites stood at attention as the brief committal service was read. The epitaph came from Admiral Dewitt C. Ramsey, commander of the Pacific Fleet, who watched from a destroyer escort. Turning to a reporter he said, 'She was a grand old ship.'” (Associated Press 1948: A-2).

The old battleship would not be forgotten; it had become an American icon. Its silver service, helm, bell and other artifacts formed a permanent exhibition at the Nevada State Museum in Carson City, and the state commemorated and celebrated the 100th anniversary of its launch in 2014 (Clifton 2014). Its community of veterans met in annual and then semi-annual reunions; newspaper and magazine stories revisited its history, especially its role at Pearl Harbor on December 7, 1941 and its role at Bikini, and a number of books were published and remain in print (Wyatt 1946, Swaney 1986, Wren and Sehe 2008, Scarpaci 2013 and Younger 2018).

\section{The Iconic Importance of USS NEVADA}

Mighty warships of the last half millennium were viewed by their respective sovereigns, the elite and their citizens as symbols of the empire or their nation. Embellished with iconic decorations and named for emperors, kings and queens, famous admirals, captains, martyred heroes, territories, or battles, they inspired pride and served as symbols of commitment to the nation-state. Some of the ships that survived wars became icons in their own right; HMS Victory, flagship of Horatio, Lord Nelson at Trafalgar, is one such icon and a symbol of British pride displayed at Portsmouth more than two centuries after its most famous battle. Its equal in the USA is the wooden frigate, USS Constitution, "Old Ironsides," preserved afloat at the Charlestown Navy Yard in Boston, and long after its 1797 launch, the oldest American warship still in commission.

A wide range of more modern warships are displayed afloat and ashore internationally, and in the USA, where some three hundred historic vessels are preserved and displayed, the largest group are ships associated with World War II, America's last great naval war. Among them are the battleships USS Alabama, (BB-60), USS Iowa (BB-61), USS Massachusetts (BB-59), USS Missouri (BB-63), USS New Jersey (BB-62), USS North Carolina (BB-55), USS Texas (BB-35), and USS Wisconsin (BB-64). Essentially obsolete weapons 
for nearly a century, they remained in use and, with their crews, were engaged in a number of battles in which they served with distinction, honor and with, at times, a heavy cost in life and limb. Venerated as powerful symbols, especially when employed in shows of force, their symbolic importance was underscored by the shedding of blood on their decks.

The christening of a battleship was a matter of great symbolic importance. They were anthropomorphized; essentially, they were seen as if the state they were named for had come to life as a gigantic steel warrior who had strapped on armor, picked up a sword, and gone to sea. The naming of battleships for the states that make up the American union not only bound those ships to those political entities, but also to their people, who made symbolic offerings such as silver services for each battleship's wardroom. More than a subject of state pride, silver services had become an "obligation," one that transformed the nineteenth century tradition of gifting ships and naval heroes with silver punch bowls, pitchers and serving trays into "a kind of disguised competition after Congress decreed in 1898, at the outbreak of the Spanish-American War, that the heaviest of these ships should carry the names of the several states" (Vivian 2002:244). By 1912, the US Navy estimated that the states' gifting silver services to its battleships had given the Navy "the finest collection....in the world" (as cited in Vivian 2002:245) (Fig. 10).

USS Nevada's launch sponsor, Eleanor Anne Siebert, who had the honor of naming the ship, was the ten-year old niece of Nevada Governor Tasker Oddie (New York Times, July 12, 1914). As a gift from "the people of Nevada," a 65-piece silver service was fashioned with 5,000 oz (96 kg) from Nevada's Tonopah mines, trimmed with gold from the state's Goldfield mines, and decorated with scenes of Nevada. Prior to the formal presentation at the ship's commissioning in March 1916, the silver service toured

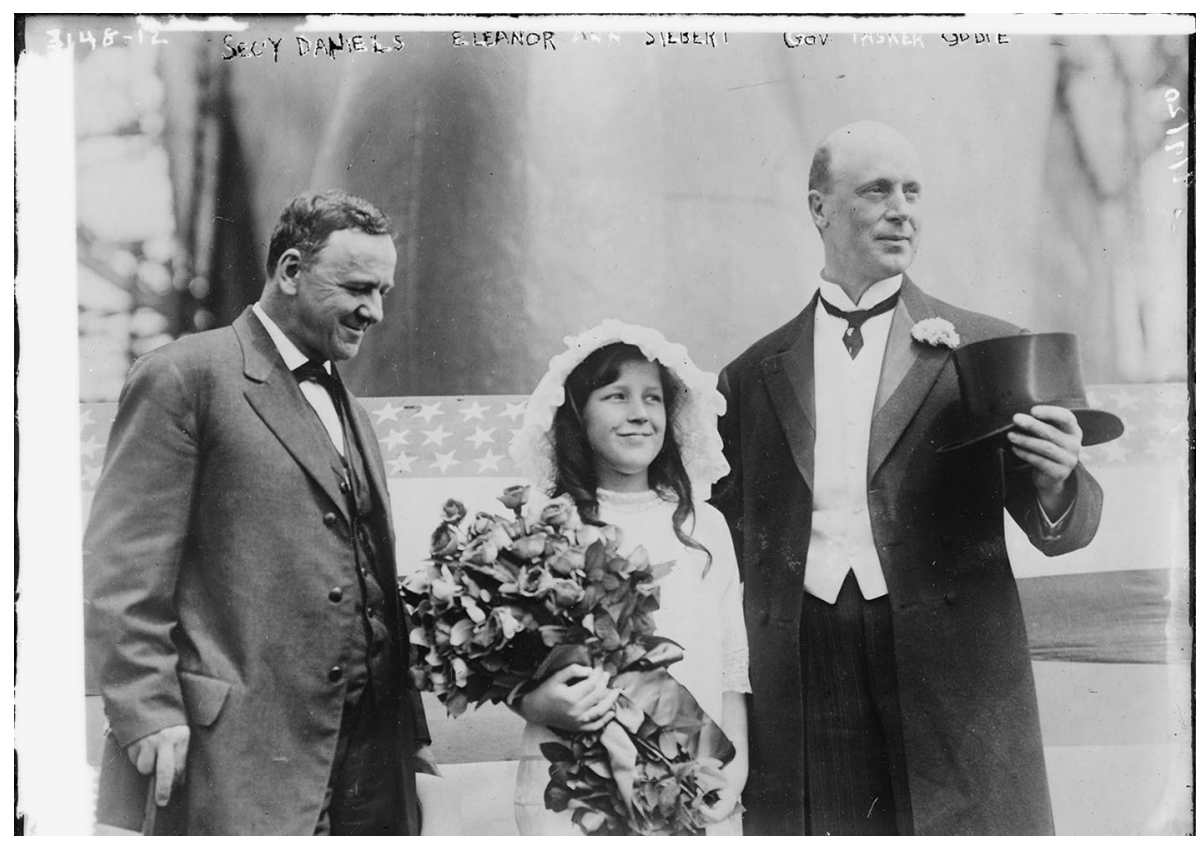

Fig. 10 Eleanor Anne Siebert with uncle, Nevada Governor Tasker Oddie (Naval History and Heritage Command/National Archives 16570u) 
Nevada on a fifteen-day tour by private rail car. It survives and is prominently displayed in the Nevada State Museum in Carson City.

Throughout the career of USS Nevada, the state's newspapers followed it closely, especially making note when a native son was posted to the battleship's company as a member of the crew. During the war, when Nevada returned to the USA after European service in 1944, "for her noteworthy combat accomplishments," Nevada's crew were presented with a chest filled with 2,100 silver dollars "on behalf of that State's citizenry," for "each man who had participated in the European invasions," after which the empty chest, emblazoned with a plaque with the Great Seal of the State of Nevada "became a prominent decoration of the ward room" (Wyatt: 1946:43).

For naval officers, the battleship was a powerful symbol

...to the average naval officer before Pearl Harbor, a navy without battleships was no navy at all. Those ships represented a way of life, they were at the core of the naval soul, and for that reason their occupants cling to them with remarkable tenacity (O’Connell 1991:7)

For the crew, serving was equated to receiving an honor, and the ship was viewed as an almost living thing; Nevada's first history, written by members of the crew in 1946, referred to Nevada with the sailor's traditional "she;" the crew's prowess in interwar gunnery exercises was noted as "a reputation for gunnery par-excellence which she never relinquished," during the attack at Pearl Harbor, at one stage, showered with burning debris, "her agony was not yet over"(Wyatt 1946:15, 20).

In the case of USS Nevada, the "survival" and "resurrection" of the battleship after Pearl Harbor, its subsequent endurance of a kamikaze strike and Japanese shells off Okinawa, and withstanding two atomic blasts made Nevada "too tough to die," as well as an symbol of American stubbornness and perseverance. The crew firing up Nevada and taking the ship out, away from Battleship Row in Pearl Harbor- "Nevada's dash" became a legend; it "gave an immediate lift to the spirits of those resisting the Japanese onslaught" (Horodyski 2020). Blogger Andy Wolf would note in a June 2019 blog that "two mindsets come to mind attempting to describe the American mindset: stubbornness and perseverance," and that if there was "a physical embodiment of those qualities it would be USS Nevada" as a "battleship that rose from her watery grave after the attack on Pearl Harbor to exact vengeance.... and refused to go down until the bitter end" (Wolf 2019).

One naval historian, writing about Nevada, noted that its sortie "at the height of the battle between aircraft and antiaircraft gunners on December 7, 1941, will forever be burned in the minds of those who witnessed. It was the finest hour for a surprised and unprepared navy" (Bonner 1996: 101). Captain C.H. Wilbur, USN (Ret.) wrote in 1995, "over forty-six years since USS Nevada...was sent to Valhalla," that "her exodus from the land of the living would have been the envy of those Viking pyres marked the passing of Norse heroes, for Nevada herself, was a truly uncommon ship. She departed in unparalleled fire and she left lessons for those who follow...." (Wilburn 1995:79).

Nevada's significance was reinforced by its selection by the military planners of Operation Crossroads to serve as the aiming point, or target ship for the first test, the aerial dropping of the 20 kiloton bomb by the B-29 "Dave's Dream." This significance, and the symbolic nature of Nevada was magnified, it can be argued, when the bomb missed and did not detonate on, and "destroy" Nevada. This reinforced the existing legend of Nevada as a ship impossible to sink. As such, in an arrayed fleet of notable and "famous" warships, Nevada arguably could be seen as the most famous Crossroads target ship. Its bright orange 
hull figures prominently in both photographs of the fleet as well as in paintings done on the scene by combat artists.

Nevada is also featured in an abstract painting by artist Ralston Crawford, part of the Crossroads team, whose photographs, meteorological charts and abstract paintings were featured in a December 1946 article about Crossroads in Fortune Magazine (Crawford 1946; Gorski 2010: 32-35). In that article, Crawford attempted "to bring home this macabre warfare" especially with abstract art with its "renunciation of direct representation" conveying "the impact of twisted ships and metal wreckage" through Crawford's abstract white, black and vermillion screen-print of Nevada as the "heart of chaos" at Bikini (Crawford 1946: 159; Jürgens-Kirchhoff 2010: 287-288; also see Gorski 2010: 35). Prints of Crawford's "USS Nevada" are found in a number of art museums, including the National Gallery of Art, the Amon Carter Museum, MoMa (Museum of Modern Art), the Portland Art Museum, the British Museum, the Museum of Fine Arts in Boston, and others.

From a veritable wreck on the surface two years before its final scuttling under naval bombardment, Nevada's symbolic importance continues, as it does for certain other submerged wrecks, even when it lies deep and "beyond" human access. This is the case for two iconic American warship wrecks in particular, the wrecks of USS Monitor (Delgado 1988) and USS Arizona (Delgado 1992), the latter a near-sister of Nevada that did not escape from Pearl Harbor on December 7, 1941 and remains there, eight decades later, surmounted by a memorial and seen as a "reservoir of sacred power" and viewed by the public and its government stewards as just as important, if not more so, than the Arizona Memorial itself (Delgado 1992: 69).

The wreck itself, as well as portions removed from it, and artifacts from the ship and its crew from December 7, 1941, are now relics imbued with symbolic importance (Delgado 1992:75-76). That significance and status stems from Arizona's unique and tragic role tied to its cataclysmic loss, with the greatest number of dead on December 7, and that Arizona today is both a tomb for some and a cenotaph for others (Delgado 1992:76). A number of Arizona's crew who survived the attack, over time, expressed a desire to return to the ship to join their shipmates in eternity, and their cremains, in urns, are interred in the barbette of the No. 4 turret (Delgado 1992:76).

By extension, Nevada, as a ship that escaped destruction at Pearl Harbor, but nonetheless was there on that day and experienced significant damage and casualties, carries the symbolic importance as a "Pearl Harbor survivor" that in time came to rest in the ocean. While Nevada sank without loss of life in 1948, its symbolism was such to Pearl Harbor survivor Captain Donald K. Ross, USN (Ret.), whose actions on the ship were acknowledged with the Congressional Medal of Honor, that his request to be buried at sea over the site of Nevada's sinking was honored by the Navy. The submarine USS Nevada (SSBN733) held a funeral service and scattered Captain Ross's ashes over the area recorded by the Navy as where Nevada sank after his death in May 1992. Like those of former USS Arizona crew, Captain Ross' last wishes reflect both the symbolic power of the vessel and a recognition of a defining moment in his life on board the ship (Fig. 11).

\section{Survey and Discovery of the Wreck}

The disposition of the various Operation Crossroads target ships saw the majority of vessels scuttled off Kwajalein; twenty-two wrecks are located there, ranging from the shallow water former German cruiser Prinz Eugen to a number of wrecks in deeper 


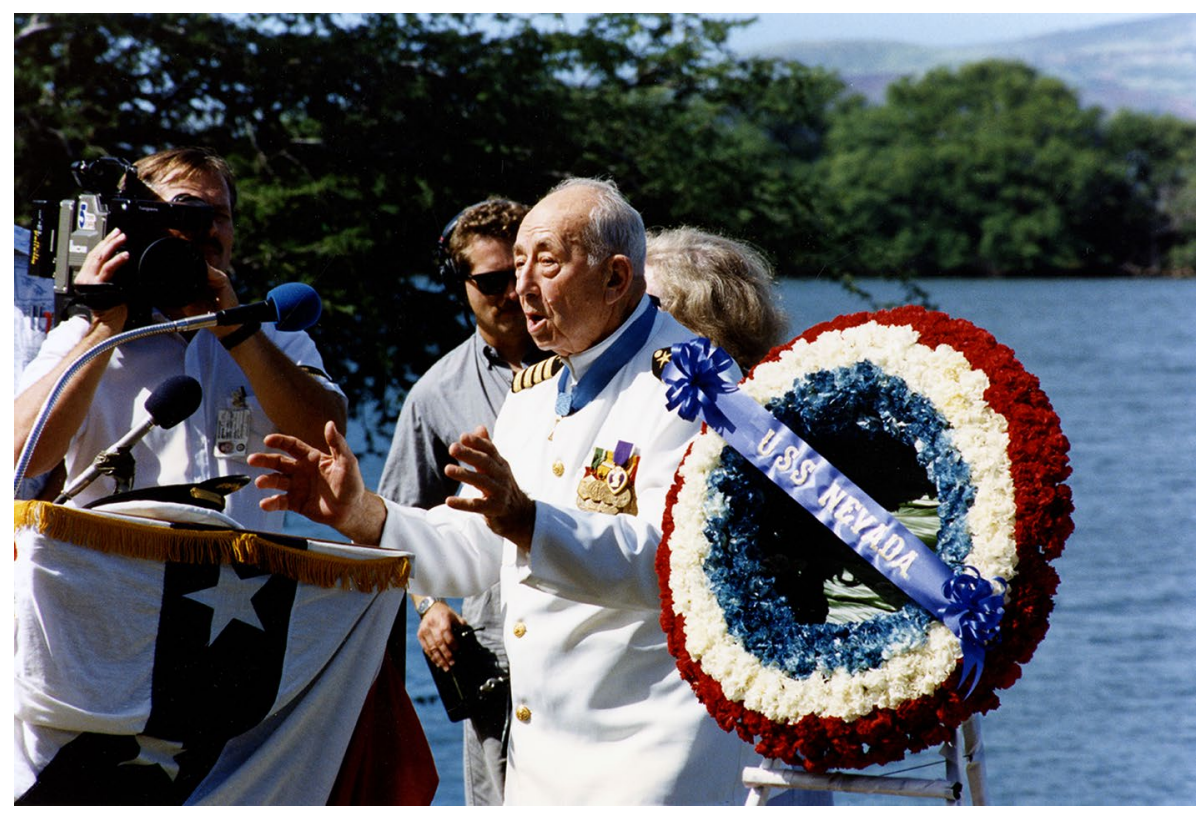

Fig. 11 Pearl Harbor survivor Captain Donald K. Ross, USN (Ret.) at the dedication of the USS Nevada Memorial, Hospital Point in 1991 (Naval History and Heritage Command/National Archives NH 97,467$\mathrm{KN})$

water (Delgado 2016a). Only two ships, USS Nevada and USS New York, were scuttled off Hawaii. Historical research in 2016 at the National Archives by Pam Orlando of NOAA's Maritime Heritage Program with the original logbooks of the three ships tasked with sinking USS New York and USS Nevada provided coordinates, as determined by each ship's navigators, of the sinking positions for the two battleships on 8 July and 31 July 1948. The positions were retained in the event that a cruise of opportunity, or a dedicated research cruise of deep ocean exploration could survey the area in an attempt to locate one or both of the wrecks.

The opportunity arose with the pending departure of Ocean Infinity's vessel Pacific Constructor in late April 2020. After a discussion between SEARCH and Ocean Infinity, they agreed to conduct an AUV survey for USS Nevada and, if found, an ROV characterization and assessment dive. The initial search deployed a single Kongsberg Maritime HUGIN AUV equipped with HiSAS (High Synthetic Aperture Sonar), which conducted a 24 -h mission at a depth of 4,715 m (15,472 ft) to survey a $259 \mathrm{sq}$. km $(10 \times 10$ nautical mile, 100-square mile) box centered on the plotted positions for Nevada's sinking as noted in the ships' logs for USS Iowa, USS Astoria and USS Pasadena. That survey located a series of objects on a muddy abyssal plain that suggested a largely intact hull with an associated debris field containing targets of various sizes (Fig. 12).

Pacific Constructor then deployed its ROV for an eight-hour dive to assess the targets. The archaeological team joined the dive remotely via Microsoft $\odot$ Teams for the entire dive with the senior author serving as the chief scientist ashore. Following the ROV dive, a second HUGIN AUV conducted a focused survey at various distances and orientations to the hull and the debris field. 


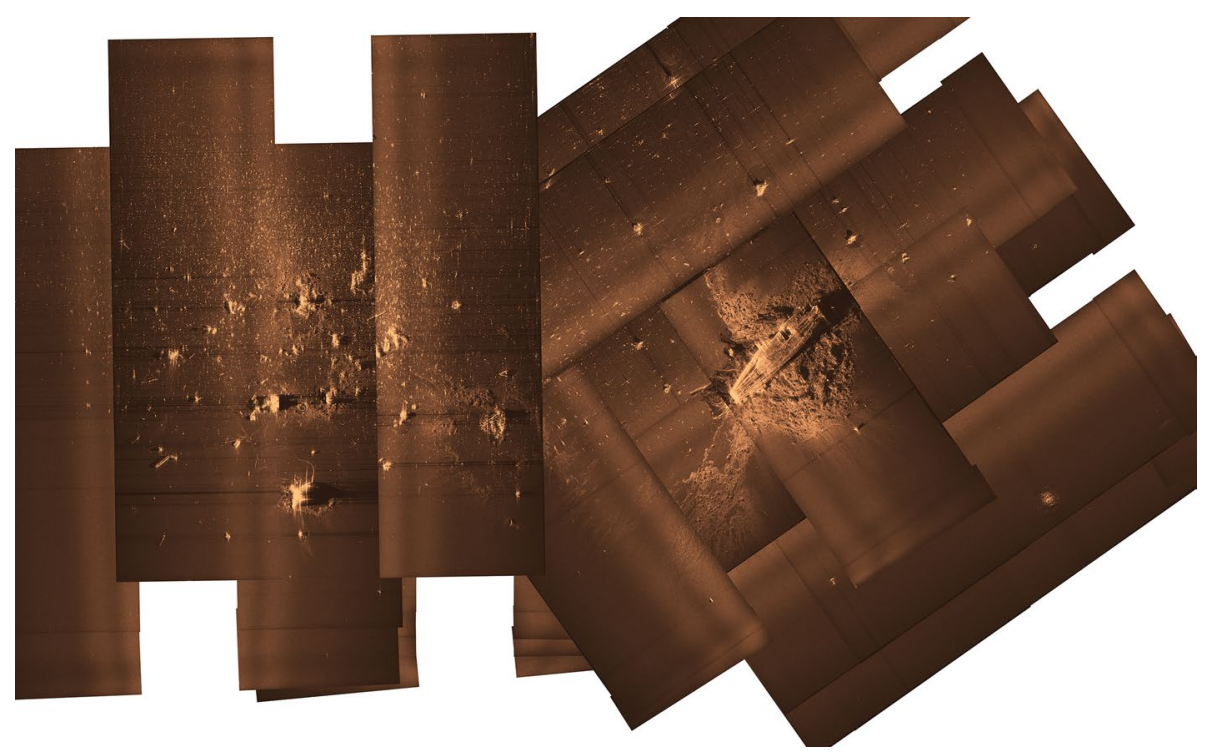

Fig. 12 Side-scan sonar mosaic of the USS Nevada shipwreck site (Ocean Infinity/SEARCH)

\section{The Wreck Site}

The wreck of USS Nevada lies on a hard sediment seabed. It is characterized by a concentrated, $850 \mathrm{~m}(2,788 \mathrm{ft})$ by $510 \mathrm{~m}(1,673 \mathrm{ft})$ debris field comprised of large disarticulated portions of the ship such as pieces of the hull, superstructure, armament and machinery, as well as artifacts from the interior of the ship and Operation Crossroads test equipment. A diminishing $450 \mathrm{~m}(1,476 \mathrm{ft})$ trail of lighter debris connects the concentrated debris field with the main body of the wreck, and then extends as a light scatter of debris some $170 \mathrm{~m}(580 \mathrm{ft})$ past the main hull in the opposite direction, making the total length of the consolidated debris field 1,470 m (4,822 ft). Some disarticulated structure from the hull rests in close proximity to the main body of the hull on the starboard side, and a detached light steel locker from a crew compartment rests near the hull at frame 100 on the port side (Fig. 12).

The average depth of the seabed is $4,715 \mathrm{~m}(15,470 \mathrm{ft})$ or $4.7 \mathrm{~km}(2.93$ miles $)$. A limited range of marine life was observed, but the wreck is largely free of marine colonization other than bacterial action, which is consuming steel and creating rusticles similar to those noted on other deep sea sites such as Titanic. The wreck retains painted surfaces with clearly defined numbers and words, and the wooden decks appear free of biological colonization or consumption. No disturbance, and hence no sampling, was made for analysis. The ROV inspection of the site maintained an average three to four meter elevation above the bottom throughout the dive. 


\section{The Hull}

The hull of USS Nevada lies capsized and slightly angled to starboard. The wreck rests in a deeply plowed rut with displaced sediment on either beam and at the bow end of the ship. Both ends of the hull at the bow and stern are missing. A small section of decking sheared off at the break of the bow upon impact with the sediment and lies angled in the seabed adjacent to the hull. The aft area of the ship is gone from about frame 120, and at the forward end, severed at a bulkhead level, the hull from about frame 40 to the bow is gone. These more lightly protected areas did not lie within the primary armored area of the ship, which was a rectangular "armor belt" of $(343 \mathrm{~mm})(13.5$-in) thick steel installed as part of Nevada's "all or nothing" armoring. This meant, and is demonstrated by, the loss of the bow and stern of Nevada when it was sunk, as the "nothing" meant no protection by armor for areas like these.

Damage to the outer skin of the hull has exposed a number of armor plates. These are high-quality, likely nickel-chromium steel Type A armor; there is no corrosion or discoloration evident on any of the exposed plates. Some of them are displaced, likely from explosive force from internal charges, naval gunfire, torpedoes or all of these. Some of the armor plate is marked from having been struck by shell fire. The bottom of the hull, exposed as it is now upright on the seabed, is relatively intact other than the damage at both ends. There is considerable distortion, however, with a number of seams in the strakes having opened (Fig. 13).

This is consistent with the Bureau of Ships Technical Inspection report on damage to USS Nevada after the Baker test of July 25, 1946, when the underwater atomic blast generated pressure waves in excess of 5300 psi. "The hull damage appears to be along the bottom between frames 82 and 98, and in way of the port and starboard blisters, frames 54 to 110" (Bureau of Ships 1946b: 18) and "Inner bottom tanks between frames 82 and 98 and wing tanks between frames 94 and 110 have partially flooded apparently through open seams in the shell plating" (Bureau of Ships 1946b: 19). Some damage may also be associated with the stresses of the prolonged effort to sink Nevada during July 26-31, 1948 as well as the impact of the hull on the seabed after a fall of the

Fig. 13 Detail side-scan sonar mosaic of the main hull of USS Nevada (Ocean Infinity/ SEARCH)

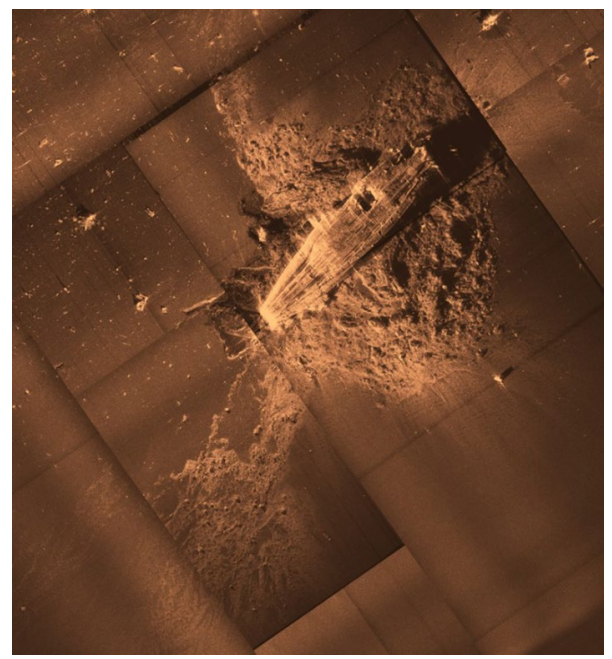


32,690-ton wreck (Bureau of Ships 1946b: 3) to the seabed, which left a pronounced impact crater.

At the stern, only one of the two propeller shafts, the starboard shaft, is present, but missing the 18 -foot $(5.48 \mathrm{~m})$ diameter, four bladed propeller. One propeller skeg is attached to the deformed shaft. The other, port shaft is missing, detached at the gland for the shaft. The flare of the outer hull as it swelled to meet the gunwale at the stern has survived on the starboard side. It is visible, inverted, at the mud level on that side of the wreck.

\section{Detached Sections of the Hull: The Bow and Stern}

Starting $400 \mathrm{~m}(1,312 \mathrm{ft})$ distant from the main hull, and aft of it, the debris field was not completely surveyed but a wide range of significant and diagnostic features were noted and documented. Two major sections of the hull, the bow and the stern, were both located. The port side of the fantail, with the hull number "36" painted as well as the Crossroads annotated " 140 " for the aft most frames (for damage assessment) were clearly visible. The survival of the bow and stern of USS Nevada are more or less intact structures in the debris field, and the condition of each indicates that they were separated from the hull early in the sinking process. The bow broke more or less on a neat line, as in shearing off immediately forward of the armor belt. The more damaged condition of the stern, with strakes twisted outward, suggests an explosion, twisting as the stern detached from the rest of the hull, as it sheared off (Fig. 14).

Historic images of the capsized, sinking Nevada indicate an intact bow and stern when the ship sank beneath the surface. It is therefore likely that the bow and stern, structurally compromised from shell fire and torpedo damage, sheared off during the vessel's descent through the water column; this likely occurred higher in the water column due to those sections' location in the initial debris field rather than adjacent to the main hull. What appears to be a torpedo track and initial impact on the capsized starboard side corresponds with

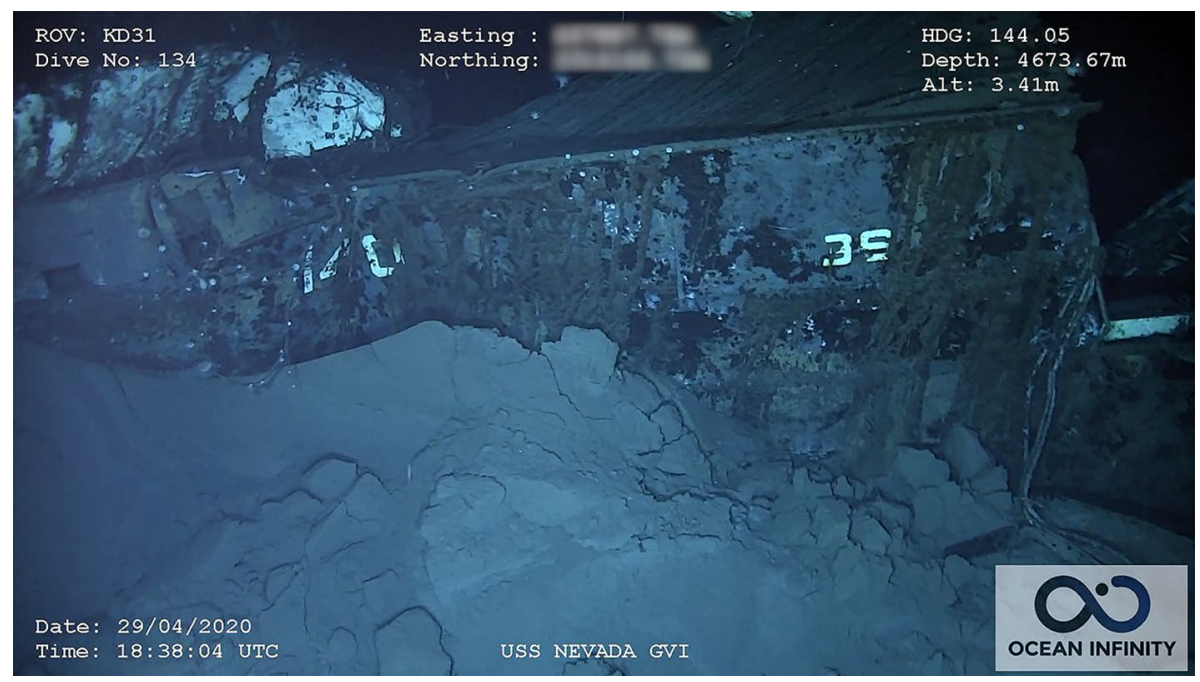

Fig. 14 Painted hull number 36 preserved on the side of USS Nevada's stern (Ocean Infinity/SEARCH) 
Fig. 15 The capsized USS Nevada begins to sink as a torpedo strikes the starboard side (Naval History and Heritage Command/National Archives 80-G-498282)

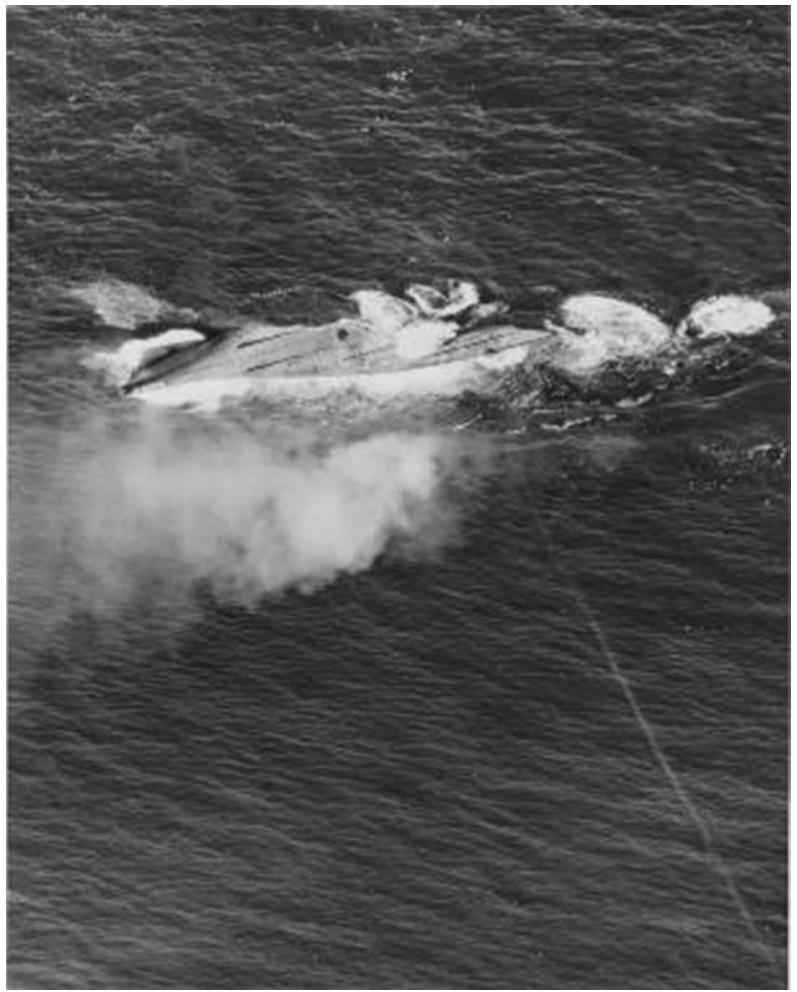

one of the locations of missing outer hullplating and damaged armor plate noted during the ROV survey of the wreck, suggesting this damage occurred at this late stage of Nevada's sinking. Depending on the amount of time the capsized hull remained at the surface, torpedo strikes may have played a role in the separation of the bow and stern (Fig. 15).

\section{Detached Section of the Hull: Torpedo Blister}

In the debris field, a section of torpedo blister was noted; it was identified through its curved structural arrangement which would have fit on the curved outer hull of Nevada above and below the waterline. While plans of Nevada from Crossroads delineate a webbed design for the frames of the blisters on Nevada, a note states that "BB36 has only W.T. webs in blister" (Bureau of Ships 1946b: 4), and that is what is visible on the wreck site.

\section{Armament}

At Crossroads, after partial stripping of armament for the atomic tests, USS Nevada retained its four turrets with ten 14-inch/45 caliber guns, but almost all of the antiaircraft guns were stripped except for four 5-inch/38 caliber guns, two twin 40-mm Bofors guns, and eight twin 20-mm guns (Bureau of Ordnance Final Report, 1946: 93, 94, 95). The survey located two of Nevada's four turrets, and one of the two remaining dual 40-mm mounts on a section of superstructure with its associated gun director. One handling room for a 5 -inch/38 caliber gun was documented, but the weapon was missing. Both turrets are 
inverted, having fallen out of the barbettes as Nevada capsized. Each turret weighs approximately 544 metric tons $(600 \mathrm{t}$ ) and were gravity-seated with hold-down clips; the clips for Turret No. 2 were broken at Crossroads by the Able detonation, and the underwater Baker test detonation and the surge of atomic-generated tsunamis partly lifted the forward turrets out of their barbettes.

Nevada's guns are of particular interest to naval historians as following the Pearl Harbor attack and the destruction of USS Arizona, three of Arizona's 14-inch guns, serial numbers 19L4, 18L3, and 17L3 from its Turret No. 2 were removed from the wreck, refurbished, and then mounted on USS Nevada in Nevada's Turret No. 1. Another Pearl Harbor battleship loss, USS Oklahoma, Nevada's sister ship, had one of its guns, serial number 76L3, installed in Nevada's Turret No. 3 in 1945. All of these guns went down with the ship and hence are on the wreck. The turret is either the No. 2 or No. 3 turret, in which case the Oklahoma Pearl Harbor gun barrel may be one of these.

A portion of the main (weather) deck forward of Turret No. 1 rests in and around the turret; the proximity of the deck would suggest that this is the No. 2 turret, and that this mass of structure from the near the bow fell close together on the seabed. The deck structure is badly damaged and there are portions of the deck which appear to be folded over one another. Visible features included a characteristic "mushroom" cap ventilator, and a portion of a hawsepipe for the bow anchors. The fore deck is an area twice damaged in the battleship's career; it was heavily damaged by Japanese aerial bombs during the Pearl Harbor attack (Fig. 16).

This area was also damaged at Crossroads by the Able detonation. The deck "forward of the superstructure, is deflected between transverse bulkheads. Maximum deflections of four to six inches appear to starboard alongside of No. 1 turret. The deck beams and supporting structure conform to the deflection of the deck and the deck beams are distorted in way of their connections to bulkheads and shell stiffeners" (Bureau of Ships 1946a: 5). The Crossroads damage was not repaired prior to sinking Nevada, which is likely a factor in the bending and folding of the structure as seen on the wreck. The compartment for shell

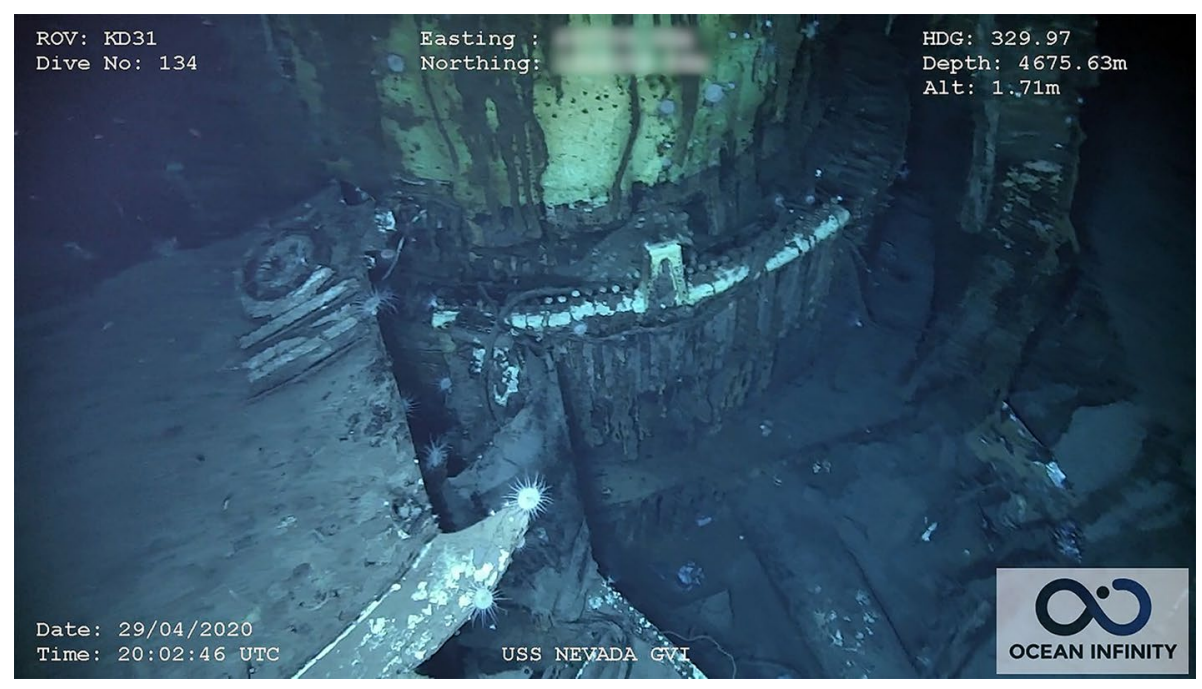

Fig. 16 Inverted turret on the wreck site. The turret sat in the barbette and rotated on the rollers visible in the image (Ocean Infinity/SEARCH) 


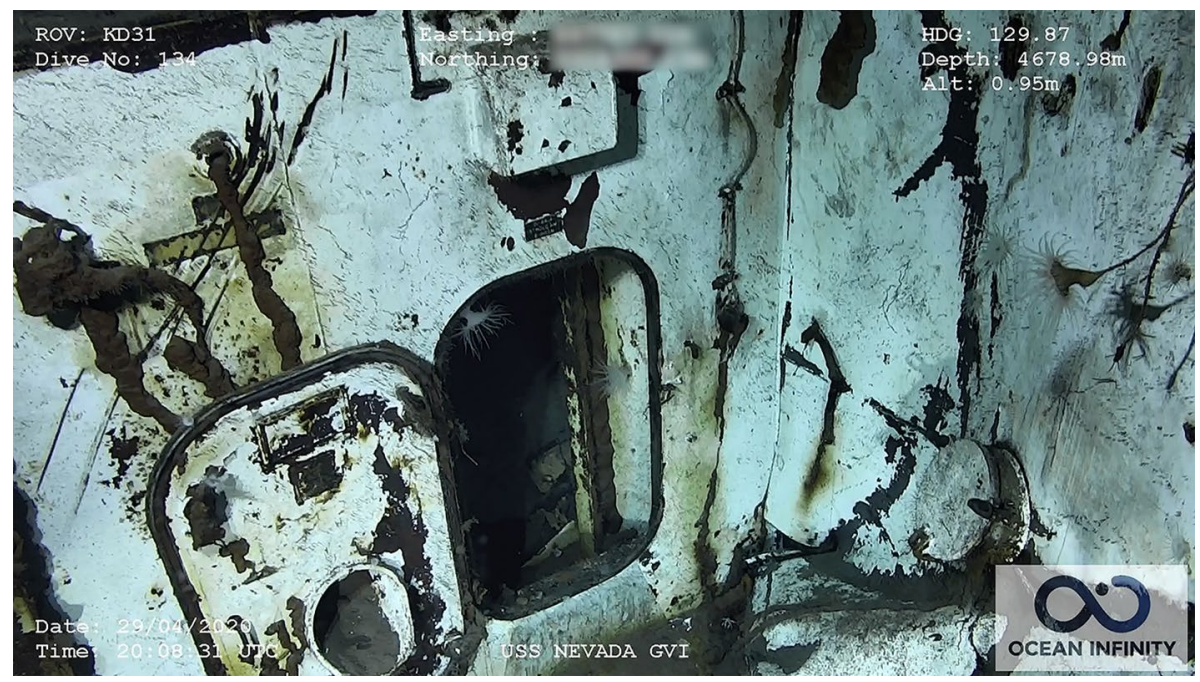

Fig. 17. 5-inch shell handling room and mount for a dual 5-inch/38 gun (Ocean Infinity/SEARCH)

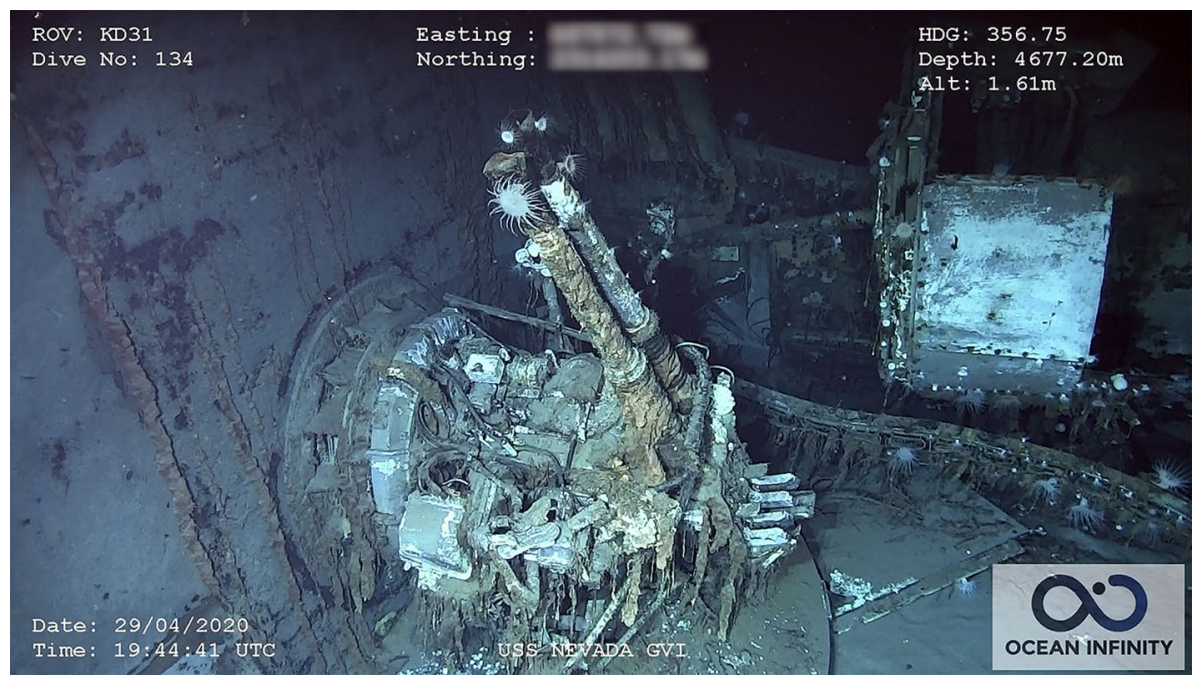

Fig. 18 Dual 40-mm mount and tub with toppled Mk 51 gun director (Ocean Infinity/SEARCH)

handling for a 5 -inch/38 caliber mount is detached from the main body of the wreck, and lies upright; it separated and appears to have wrenched free from the larger wreck.

The compartment comes from the superstructure deck and retains its engraved designation of "01-64-4 5" HDLG RM B-0102 M" which indicates it was midships between frames 45 and 75 . While this was the only engraving noted on the ROV dive, others likely survive and provide specific information for locating where wreckage was located on the ship prior to the wrecking event (Fig. 17). 
The final piece of armament observed on the site was a dual-mount 40-mm Bofors antiaircraft gun, still mounted and with its associated Mark 51 gun director in its tub. 40-mm mounts like this were situated around the ship as part of the late-war effort to increase protection against enemy aerial attack; Nevada was twice damaged by aerial attack (Pearl Harbor and Okinawa) (Fig. 18).

\section{Superstructure}

Large pieces of Nevada's superstructure were also observed in the debris field. Formed around a large steel tripod foremast, the superstructure includes compartments such as the Captain's Cabin, the Combat Information center (CIC), the Navigation Bridge, the Flag Bridge, the Air Defense Bridge, Secondary Battery Fire Control, Lookout stations, and Radar and Gun Directors. What appears to be the top of the tripod foremast lies close to the section of mast with the various command bridges. There is shell fire damage (Fig. 19).

\section{Deck Equipment}

Various items of deck equipment were noted in the debris field. They included a winch, the aircraft handling crane from the stern, and the airplane catapult for Nevada's OS2U Kingfisher spotter plane. The crane was at the stern, and was reported knocked down by the Able blast at Bikini, which also wrecked Nevada's spotter plane. The crew jettisoned the Kingfisher at Bikini after Able. The catapult, also at the stern, occupied much of the fantail.

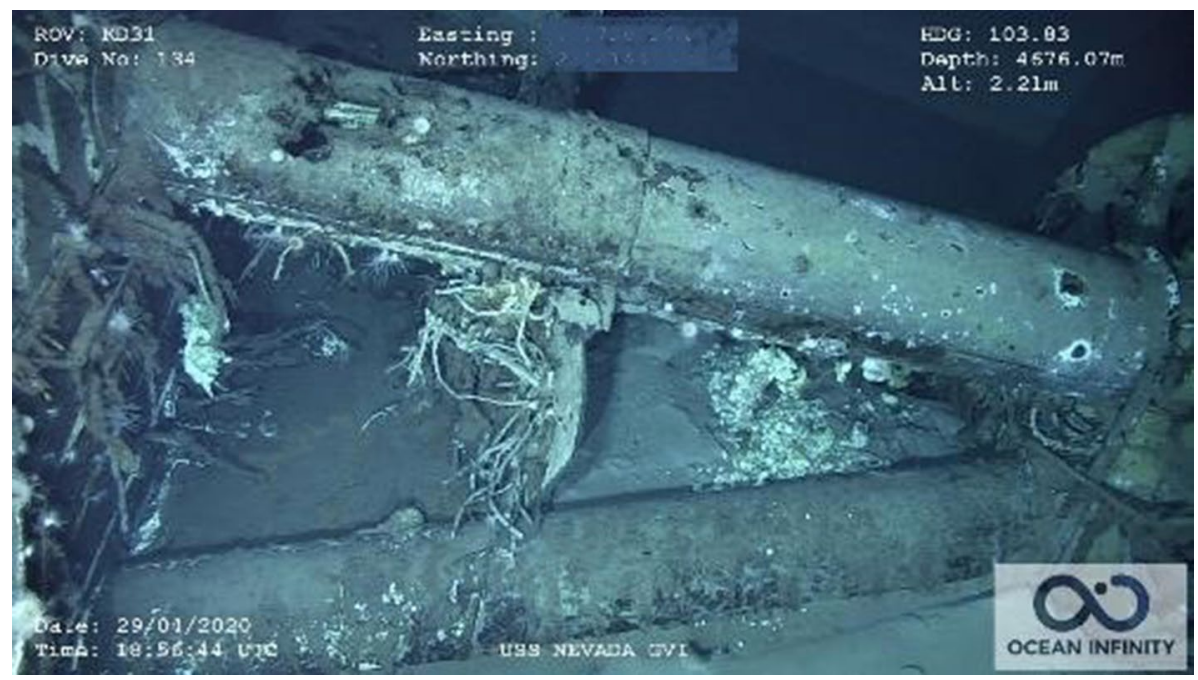

Fig. 19 Shell fire damage to the tripod foremast (Ocean Infinity/SEARCH) 


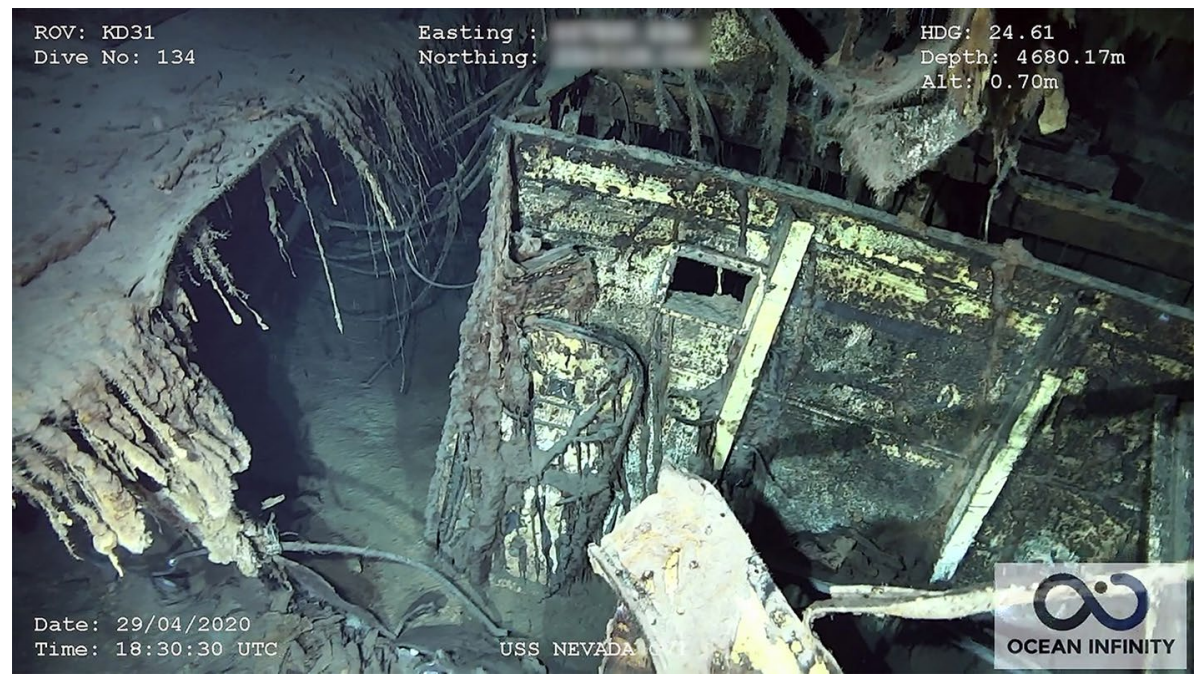

Fig. 20 View aft toward the aft compartment with a watertight bulkhead and hatch, shut for Condition $\mathrm{X}$-Ray (Ocean Infinity/SEARCH)

\section{Crew Compartments}

A large number of structural remains from the superstructure included identifiable sections of interior compartments, as well as the previously mentioned crew compartments noted in the wreckage of the stern (Fig. 20). These were noted and filmed, but not all received detailed inspection. These areas of the ship came from the disintegration, through explosive destruction, of the bow, stern and the superstructure, an area which comprised crew quarters that occupied the former area of casemated 5 -inch $/ 51$ caliber guns in what was called the "aircastle." This area was converted from a secondary battery space to crew accommodations in the 1927-1930 remodeling of USS Nevada. Other ships retained the guns but also berthed crew in the casemates. One section of wreckage located was from the starboard casemates at frame 60; it was identified by the survival of the frame number, painted on the ship for Operation Crossroads damage assessments. Images of Nevada under shelling and aerial attack during the sinking exercise in July 1948 show this section of the ship damaged but relatively intact, with the frame number visible, as is frame 50.

\section{Life on Board}

The focus on larger sections of the wreck in the debris field did not leave time to stop to assess smaller artifacts and structure, but they were observed and ongoing review of the dive footage will continue to assess and identify artifacts and structure. Among these were the reminders that USS Nevada was a ship that was the floating home for its crew, and the setting for key and powerful experiences, including death.

Equipment from the galleys was also observed. Two examples are a cooking pot and what appears to be a kettle, both of them partly buried in soft sediment. Nevada did 
not sink as an emptied ship. In addition to the ship's equipment and gear, the crew of Nevada left the ship for the atomic bomb tests as if it were in "actual battle conditions:"

...crew member's beds were made, then covered with fire-proof mattress covers; officers cabins were left as if the men had answered a sudden summons to General Quarters; bunks were made up, clothes were hanging behind a fireproof barrier, and drawers were full of shirts and underclothes; pens and stationary were on the desks; the wardroom's record player was turned off but was still plugged into the outlet with "Trolley Song" in place on the player; dishes were on tables and silverware beside dinner plates, and glasses and cups and saucers were properly in place (Swaney 1986: 124).

A physical reminder of this is a shoe lying on the sea bed next to a ladder. We usually see these on sites where a ship with its crew has sunk in battle. While Nevada sank after three simulated battles, two against atomic bombs and one against explosive charges, shells and torpedoes, we were very aware that the ship was a home as well as a weapon of war. Men did die on Nevada in battle as well as in peacetime service. Decades after its sinking, the site of Nevada's scuttle was the site where the ashes of Nevada's own, who had served and sacrificed, were scattered on the waves to rejoin this shattered hulk. We conducted our work with respect and to honor those who built, served, fought and died on this ship.

\section{Evidence of Operation Crossroads}

Artifacts and aspects of the wreck reflect its use as a target vessel for Operation Crossroads, the July 1946 tests of the atomic bomb. An obvious question is whether the ship retains the bright "international orange" coat of paint applied as it was selected as the aiming point for the first test, Able, where the bomb would be dropped from a B-29 to explode directly above the battleship. The bomb missed Nevada. It was difficult to determine if any of the

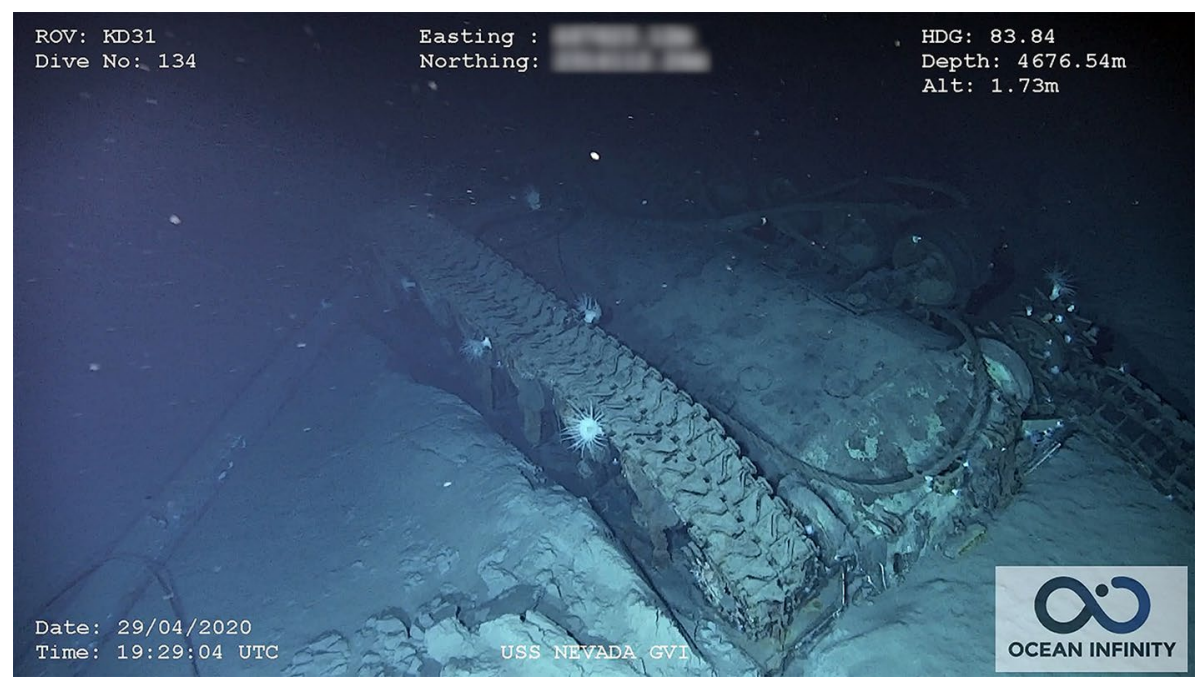

Fig. 21 Overturned Crossroads Test Tank from the deck of USS Nevada (Ocean Infinity/SEARCH) 
paint that survived on the ship's hull was orange, but at times, as the ROV approached closer, some of the paint had hints of orange. Other painted "signs" of Crossroads, such as the draft marks and frame numbers, were clearly visible.

The ROV survey initially located one definite Crossroads test item and another probable one. One of the tanks, snarled with the steel cable used to turnbuckle and fasten it to the deck, lies upside down (Fig. 21). There is no visible trace of the turret and gun, which appears to have unseated and fallen off. A square, heavy structure which appears to be a base or mount for samples or instrumentation was also observed. More research is required, but it stands out as not being part of the ship.

\section{Site Formation Processes}

The physical evidence on the seabed in the form of site distribution patterns provides empirical evidence of the final moments of Nevada as a cohesive entity, i.e., a "ship" as opposed to a scattered area of debris that constitutes a shipwreck site. As Church (2014, 2016) has noted, the sinking of a steel-hulled vessel is a violent event that leaves a trail of debris as increased water pressure forces air to vent rapidly, with some compartments imploding as the wreck gains speed, "quickly reaching a velocity of 10-14 m per second (19-27.5 knots)...The upper structures of most vessels are not designed to endure the forces of drag...portions of the vessel break away...a vessel typically impacts the seafloor forcefully, displacing massive amounts of sediment...the hull frequently buckles and decks collapse" (Church 2016: 249). These processes are not random and they are repeated in a variety of sites. Based on work on a series of modern steel-hulled wrecks, Church (2016:250-251) postulates a site formation process for these types of sites "distributed with mathematical consistency" with an equation of site distribution that calculates 20 percent of the depth of water (w) plus the length of the hull (vl) to determine the limits of the site boundary:

$$
0.20 \mathrm{w}+\mathrm{vl}=\text { site boundary }
$$

For USS Nevada, applying Church's equation, this would be 20 percent of the $4715 \mathrm{~m}$ $(15,427 \mathrm{ft})$ deep water plus the $178 \mathrm{~m}$ (583 ft) length of Nevada's hull, or:

$$
943 \mathrm{~m}(3,093 \mathrm{ft})+178 \mathrm{~m}(583 \mathrm{ft})=1121 \mathrm{~m}(3,677 \mathrm{ft})
$$

The consolidated debris field of USS Nevada is $1,470 \mathrm{~m}(4,822 \mathrm{ft})$; however, the main concentration of heavy debris is an $850 \mathrm{~m}(2,788 \mathrm{ft})$ area. This evidence does not contradict Church's model in our opinion. Nevada, adrift on the surface for four days and subjected to intensive bombardment, lost structure that sank prior to the final day, at which point the hull capsized after aerial torpedo hits. At that stage, loose structure, deck equipment and the gravity-seated turrets fell free of the hull in a straight fall to the seabed nearly three miles below. The hull submerged, stern first, and then glided at steep angle to strike the seabed approximately $510 \mathrm{~m}(1,673 \mathrm{ft})$ from the position on the surface at which it sank, which we calculate at the center of the concentrated debris field. The stern is closest to the debris field, and at an acute angle, which suggests the hull rotated as it sank, which may account for the lighter, less concentrated field of smaller debris that surrounds the main hull.

The main hull, when it struck the seabed, hit with considerable force and at an angle that saw the capsized edge of the port side of the hull plow into the sediment to create a 
mounded field of disturbed sediment along that beam of the wreck for some $140 \mathrm{~m}(459 \mathrm{ft})$. This is compared to a lighter field of displaced sediment and ejecta on the other side of the hull that is approximately half the area of that on the port side. Following this final, violent action, the wreck settled onto the dense sediment of the seabed where for 72 years it remained, unobserved, as the components of the wreck site were subjected to what appears to be a slow-paced biochemical deterioration, as few rusticles were observed and the hull retained paint on all surfaces with little biological growth observed on the site. This is similar to observations made on the condition of other contemporary deep-water discoveries of World War II-era vessels in the Pacific region, such as USS Indianapolis, USS Lexington, USS Hornet, or the Imperial Japanese Navy carrier HIJMS Kaga, for example.

Finally, as noted earlier, there is much that can be inferred and learned from the wreck of USS Nevada. It is an artifact that speaks to naval development, the shifting role of battleships from the epitome of naval power to obsolescence, and as a floating community which would be evacuated for the atomic tests, left behind much that spoke to the human presence on Nevada. A reminder of that was found on the back of one of the two turrets spotted during the survey, where a Leading Seaman Lopes (as yet unidentified) "tagged," in modern parlance, the turret with his rank and name.

\section{USS NEVADA as an Artifact}

As the second quarter of the twenty-first century approaches, Nevada, as an archaeological site and as a sunken structure, is an artifact that tangibly links current and future generations to a type and class of warship that, while obsolescent, "defined" naval warfare more than a century ago even as submarines and aircraft began to change the concepts and practice of naval warfare. As one of the battleships badly damaged and with loss of life at Pearl Harbor, Nevada, like other battleships already a symbol of American naval power, assumed a new symbolic role as a stubborn ship whose crew refused to let it "die." The ongoing role of Nevada in World War II reflects more than its near-loss and the heroic actions of its crew at Pearl Harbor. Salvaged and rebuilt in 1942, Nevada also reflects the US Navy's readjustment of battleship roles in the face of war after 1941 and the loss and near-loss of battleships in the aerial assault on Pearl Harbor (Martin 2012:2).

The four oldest battleships that served in the US Navy in World War II, in one sense, can be accessed in the twenty-first century through the physical survival of USS Texas (BB-35), afloat and on display outside of Houston. At the same time, its sisters Arkansas (BB-33), New York (BB-34) and Nevada (BB-36) also physically survive as archaeological sites and as artifacts on the seabed. Unlike Texas, which is an artifact of a career and modifications that saw its final role in providing shore bombardment in advance of amphibious landings, the three other battleships are also artifacts of the Cold War, specifically as artifacts of the advent of the atomic age and the development of nuclear weapons. This latter destructive deployment and loss of the three battleships can also be seen, as Martin argues for USS Texas, as the means by which the oldest American battle ships continued to gain relevance in the face of their obsolescence (Martin 2012).

Even as wrecks, or macro-artifacts, these battleship wrecks have a new relevance as archaeological sites. Daniel Lenihan, principal investigator for the National Park Service's archaeological documentation of the Crossroads fleet at Bikini in 1989-1990, noted their symbolic attributes give them "power as touchstones to the past-a point at which the relative values of history become entangled in the less yielding fabric of archaeology" 
(Lenihan 2013: 288). Lenihan also notes, emphasizing and adding to a theme inherent in the 1989-1990 work at Bikini, that the ships were sacrificed in an act of conspicuous consumption and as a demonstration of wealth, strength and power by the USA (Delgado et al. 1991: 21; Lenihan 2013: 292-293).

The archaeology of Operation Crossroads, as previously noted, has in time become integrated more into the growing area of emphasis of study known as the archaeology of the Cold War, in which Todd Hanson in particular has drawn a larger context of the Cold War cultural landscape (Hanson 2016a). Central in this landscape is that it is associated with the research into, development and production of, the testing and military use of atomic weapons, as well as theoretical constructs such as conflict archaeology, contemporary archaeology and the archaeology of science (Hanson 2016a: 123). Also key is the question of secrecy, because of secrecy's central role in the Cold War, "issues of secrets and secret-keeping confront archaeologists of the Cold War every day...even as the secrets are revealed over time" primarily through declassification (Hanson 2016a: 131).

In this context, as noted previously with USS Independence, the survey for and initial documentation of USS Nevada did not discover a wreck that was "lost" (Delgado et al. 2018a, b: 140). Hanson aptly pointed out that in the context of the Cold War, "lost" is a "slippery concept as its meaning may range from some whose location is genuinely unknown to a location that is known, but closely guarded by national security secrecy" (Hanson 2016a, b:8). The logbooks of the ships involved in sinking USS Nevada remained classified, first in the Naval History and Heritage Command's Operational Archives Division and then in the National Archives. The 2020 project would not have happened without the ultimate declassification of the logs in more recent times.

As was observed at Bikini with the ships there in 1989-1990 (Delgado et al. 1991) and most recently with the deep-water archaeological assessment of USS Independence, which was also scuttled post-Crossroads in distant seas far from Bikini, the inspection of these wrecks is able to assess and correlate damage inflicted by the nuclear tests at the site. This initial examination of Nevada could be coupled with detailed examination of the now-declassified post-test assessments of the damage (documents that remained classified during the initial Bikini work at the end of the Cold War). The level and type of damage visible on the Nevada wreck goes beyond official declassified accounts that stress the gross physicality of the damage that dramatically noted how "the scorched port quarter of the Nevada, blackened from waterline to top deck, is evidence of the consuming heat" and how "the big battlewagon's superstructure has been heavily damaged, as indicated by the torn smokestack and bent antenna" (Historian, Joint Task Force One 1946: 169). The classified reports, now declassified, and the physical, archaeological remains reveal radiation levels that could not be "cleaned off" or removed, as well as insidious damage to electronics, antennae and other systems. This directly confronts and challenges the notion of a ship that could not die. As previously noted, had Nevada been crewed, they would have all died, and the ship itself, unable to communicate, unable to steam, unable to fight, was also dead. Symbolism and romance aside, the naval exercise of 1948 tore apart and sank a steel corpse both awash in the trough of the sea as well as by sentiment by the people of the Navy but not by politicians, scientists and military leaders.

That steel corpse, now relocated and surveyed, offers more empirical and archaeological evidence of Operation Crossroads as well as USS Nevada. This adds detail to the ongoing assessment of the larger, Pacific-wide maritime cultural landscape associated with Operation Crossroads, and by extension the larger Cold War maritime cultural landscape that spans not only the Pacific, but the entire globe. A symbolic ship, rediscovered in the time of the global COVID-19 pandemic, again proved a powerful symbol of resilience and 
stubbornness demonstrated by a ship that it's crew would not let die, that a nation resurrected from the mud of Pearl Harbor to fight in a new role, and then ultimately sacrificed in the context of an unwinnable war if the Cold War had gone "hot."

USS Nevada powerfully speaks to the ultimate context, as do the sunken ships and abandoned bunkers at Bikini, of what might have been if a global exchange of nuclear weapons had left nothing but irradiated ruins where cities once stood, where mighty ships lay broken and irradiated in the depths, and broken aircraft lay cratered into the ground or seabed where they had fallen in the last days of humanity. The other side of Nevada's story is, therefore, not that it was not just a ship that could not die, but as we examine its wreckage, we see what forces were at play that did bring about the "death" of USS Nevada. As Todd Hanson (2016a, b: 153) notes, the archaeologies of the Cold War "will help us tell stories that clarify, depoliticize and humanize a conflict and era that was so deeply shrouded in mystery, so perversely dogmatic, and so implausibly nationalistic that it almost defies belief."

\section{References}

Army Ground Group (Task Group 1.4) (1946) Final report of atomic bomb tests, 4. XRD-152

Associated Press (1948) Navy blasts battleship Nevada four days to sink her at sea, Washington, D.C. Evening Star, July 31: A-2.

Austin American (1946) Geiger counter prophesied as future watchdog of home, Austin American, September 15: 24.

Berkhouse L, Davis SE, Gladeck FR, Hallowell JH, Jones CB, Martin EJ, MacMullan FW, Osborne MJ (1984) Operation Crossroads (1946). Defense Nuclear Agency, Washington, DC

Bonner, Kermit "Kit" (1996) Final voyages. Turner Publishing Company, Paducah, Kentucky.

Bureau of Ordnance Group (1946) Final technical inspection report, Operation Crossroads, Tests 'A' and 'B' 1, Parts I Through VII. XRV-158.

Bureau of Ships (1946a) Technical inspection report, USS Nevada (BB36) test able. National Archives Record Group 374, National Archives, Washington, D.C.

Bureau of Ships (1946b) Technical inspection report, USS Nevada (BB36) Test Baker. National Archives Record Group 374, National Archives, Washington, D.C.

Campbell J (1985) Naval weapons of world war two. Naval Institute Press, Annapolis

Church RA (2014) Deep-water shipwreck initial site formation: the equation of site distribution. J Marit Archaeol 9(1):27-40

Church RA (2016) The U-166 and Robert E. Lee battlefield: the equation of site distribution. In: Keith ME (ed) Site formation processes of submerged shipwrecks. University Press of Florida, Gainesville, pp 249-258

Clifton G (2014) State marks $100^{\text {th }}$ anniversary of USS Nevada, Reno Gazette-Journal, July 13. https:// elkodaily.com/news/state-marks-th-anniversary-of-uss-nevada/article_7fd62b7a-0aaf-11e4-a22c0019bb2963f4.html

Cox OL (1916) U.S.S. Nevada: Description and trials. J Am Soc Naval Eng, XXVIII (1), February: 20-54.

Crawford, Ralston (1946) Bikini, Fortune, December, 34(6): 154-159.

Delgado JP (1988) A symbol of american ingenuity: assessing the significance of USS monitor. U.S. Government Printing Office, Washington, D.C.

Delgado JP (1992) Recovering the past of USS Arizona: symbolism, myth, and reality. Hist Archaeol 26(4):69-80

Delgado JP (1996) Ghost fleet: the lost ships of bikini atoll. University of Hawaii Press, Honolulu

Delgado JP (2016a) After crossroads: the fate of the atomic bomb target fleet. J Marit Archaeol 11(1):25-31

Delgado JP, Daniel JL, Larry M (1991) The archeology of the atomic bomb: a submerged cultural resources assessment of the sunken fleet of operation crossroads at Bikini and Kwajalein Atoll Lagoons, Republic of the Marshall Islands. Submerged Cultural Resources Unit, National Maritime Initiative, Santa Fe and Washington, D.C. 
Delgado JP, Brennan ML, Roletto J, Cantelas F, Matthews R, Elliot K, Vetter K, Figueroa C, LickliterMundon M, Schwemmer RV (2017) Exploration and mapping of USS Independence. Oceanography XXX(1) Supplement:34-35

Delgado JP, Brennan ML, Elliott K, Mathews RE, Lickliter-Mundon M, Lambert JG, Cantelas F, Schwemmer RV (2018a) Archaeological survey of the ex-USS Independence (CVL-22). J Marit Archaeol 13(2):123-144

Delgado JP, Matthews RE, Lickliter-Mundon M, Brennan ML, Lambert JG (2018b) USS Independence's Aircraft. J Marit Archaeol 13(2):145-166

Director of Ship Material (1946)a historical report, atomic bomb tests able and baker (Operation Crossroads), XRD 190.

Fanning RW (1995) Peace and disarmament: naval rivalry \& arms control. University Press of Kentucky, Lexington

Fee JJ (1946) Director of ship material technical report, radiological decontamination of target and nontarget vessels, Operation Crossroads, Joint Task Force One, AD-473 906

Friedman N (1978) battleship design and development, 1905-1945. Conway Maritime Press

Friedman N (1985) U.S. battleships: an illustrated design history. United States Naval Institute Press, Annapolis.

Gardiner R, Chesneau R, Roger, (eds) (1980) Conway's all the world's fighting ships, 1922-1946. United States Naval Institute Press, Annapolis

Gorski SB (2010) The artist, the atom, and the bikini atoll: ralston crawford paints operation crossroads, M.A. Thesis, University of Texas at Austin,

Hansen C (1988) U.S. Nuclear Weapons: The Secret History. AeroFax, Arlington, Texas.

Hanson TA (2016a) Being Sine Que Non: maritime archaeology and the archaeology of the cold war. J Marit Archaeol 11(1):5-8

Hanson TA (2016b) The archaeology of the cold war. University Press of Florida, Gainesville

Historian, Task Force One (1946) Operation crossroads: the official pictorial record. William H. Wise, New York.

Horodyski JM (2020) This is how the battleship USS Nevada survived Japan's attack on Pearl Harbor, Warfare history network, The National Interest (blog), January 20, https://nationalinterest.org/blog/buzz/ how-battleship-uss-nevada-survived-japans-attack-pearl-harbor-110351

Jordan J (2011) Warships after Washington: the development of the Five Major Fleets 1922-1930. Seaforth Publishing, Barnsley

Jürgens-Kirchhoff A (2010) Representations of War in American Art after 1945, in George Schild, ed. The American Experience of War, Ferdinand Schöningh, Paderborn, Munich, Vienna and Zurich, 287-312.

Lenihan DJ (2013) Bikini atoll: abandoning hot ships in a cold war, in Nathan Richards and Sami Kay Seeb, eds. The Archaeology of Watercraft Abandonment. Springer, New York, pp 279-296.

Madsen D (2003) Resurrection: salvaging the battle fleet at Pearl Harbor. United States Naval Institute Press, Annapolis, Maryland

Martin K (2012) Gaining relevance in the face of obsolescence: The USS Texas - a battleship in the second world war. University of New Orleans Theses and Dissertations. 1599. https://scholarworks.uno.edu/ $\mathrm{td} / 1599$

Morison SL, Polmar N (2003) The American battleship. MBI, St. Paul, Minnesota

O'Connell RL (1991 )Sacred vessels: the cult of the battleship and the Rise of the U.S. Navy. Westview Press, Boulder, Colorado.

Phillips J, Klemm J, Goetz J 1985 Internal dose assessment - operation crossroads. Technical Report Prepared for Director, Defense Nuclear Agency. DNA-TR-84-119. https://www.dtra.mil/Portals/61/ Documents/NTPR/4-Rad_Exp_Rpts/25_DNA-TR-84-119_Internal_Dose_Assessment-Operation_ CROSSROADS.pdf

Power H (1993) Battleship texas. Texas A\&M University Press, College Station

Scarpaci W (2013) Battleship Nevada: The extraordinary ship of firsts. Create Space Independent Publishing Platform.

Scarpaci W (2014) The Saga of the USS Nevada. Nevada magazine. 74 (4), July/August: 70-78.

Shurcliff WA (1947) Bombs at bikini: the official report of operation crossroads. William H. Wise \& Co., New York

Swaney ES (1986) Operation crossroads: a personalized story of one of America's most famous battleships, the U.S.S. Nevada (BB36). Sutherland Publishing, Montezuma, Iowa.

United States Naval Institute (1948) Professional Notes, Proceedings, 74 (546):1036.

Vivian JF (2002) "An Arizona obligation": the story of the State's Gifts to the USS Arizona. J Arizona His 43(3):237-262

Wagoner R (1948) Bat Bombs Miss USS Nevada in barrage test, The Sacramento Bee, July 31: 16. 
Wallin HN (1968) Pearl Harbor: how, why, fleet salvage and final appraisal. Department of the Navy, Washington, D.C.

Weisgall JM (1994) Operation crossroads: the atomic tests at bikini atoll. United States Naval Institute Press, Annapolis

Wilburn CH (1995) The remarkable Nevada story. Nav Eng J 107(5):79-83

Wolf A (2019) The battleship that wouldn't sink: how the USS Nevada became a symbol of the American fighter during WWII, War is Boring (blog), https://warisboring.com/the-battleship-that-wouldnt-sinkhow-the-uss-nevada-became-a-symbol-of-the-american-fighter-during-wwii/

Wren LP, Charles TS (2008) Battle born: the unsinkable USS Nevada BB-36. Xlibris, Bloomington, Indiana.

Wyatt WS (ed) (1946) U.S.S. Nevada: 1912-1946. Ship's Welfare Department, USS Nevada.

Younger SM (2018) Silver seas dreadnought: the remarkable story of battleship Nevada. United States Naval Institute Press, Annapolis, Maryland

Publisher's Note Springer Nature remains neutral with regard to jurisdictional claims in published maps and institutional affiliations. 